\title{
Merchant Capital, Taxation \& Urbanisation. The City of Ani in the Global Long Thirteenth Century
}

\author{
Nicholas S. M. Matheou*
}

This article addresses the themes of urban agency and state-centrism by analysing the agency of merchant capital and taxation in processes of urbanisation. The case study is the city of Ani, a now abandoned site in central south Caucasia straddling the Turkish-Armenian border, in the long thirteenth century c.1200-1350. This global-historical conjuncture is defined by the height of the medieval Commercial Revolution and its central Eurasian expression, the Silk Road. By 1200 Ani had developed as a thriving commercial centre for over two hundred years, with merchants coming to dominate the political economy in the city and its environs. By the mid-fourteenth century, however, this wealthy commercial class was no longer in evidence, with Ani's urbanising process fundamentally transformed, beginning a rapid deurbanisation. Utilising contemporary theories of (de)urbanisation found in Ibn Khaldūn's Muqaddima, this article first outlines Ani's development up to 1200, focusing on the role of interregional and intercontinental commerce, and the urban elite's rising dominance in landholding. Having established the mercantile and rentier regime of accumulation on which Ani's development depended, we turn to the period of Zakarian-Mkhargrdzeli rule under the Georgian kingdom c.1200-1236, finding a wealthy commercial class hegemonic in the city's political regime as well as the regime of accumulation. The final section, then, details the urban elite's fortunes under Mongol Eurasian hegemony, and particularly the effects of drastically increased taxation in this political realisation of the medieval Silk Road. Ultimately the story of Ani in the global long thirteenth century forms a crucial case study for the combined agency of taxation and capital in urbanisation, both beneath and within the level of the state system, speaking to their contradictory symbiosis. At the same time, the city as a site of accumulation forms a crucial bridge in the Armenian merchant bourgeoisie's trajectory from the medieval Commercial Revolution into the coalescence of capitalist modernity.

Keywords: Armenia/Armenians, capitalism, cities, Commercial Revolution, Georgia/Georgians, epigraphy, Ilkhanate, merchants, Mongols, political economy, Silk Road, states, taxation, world systems

* Correspondence details: Nicholas S. M. Matheou, Armenian Institute, London; nik@armenianinstitute.org.uk, nikmatheou@gmail.com.

This article is part of the themed section Urban Agencies: Reframing Anatolian and Caucasian Cities (13th-14th Centuries), guest editors: Bruno De Nicola and Matthew Kinloch. To read all related articles, please access: dx.doi. org/10.1553/medievalworlds_no14_2021. 


\section{Introduction}

In his Muqaddima (1377), a long theoretical introduction to a multi-volume universal history, the Maghrebi jurist and scholar Ibn Khaldūn (1332-1406) provides an astute analysis of the preconditions, dynamics and tendencies of urbanisation. ${ }^{1}$ Most decisive is a political regime: cities are not socially necessary but are rather inextricable from state systems, ${ }^{2}$ his vision of "civilisation « encompassing both state formation and urbanisation so that the latter "completes " the former. ${ }^{3}$ Delineating further necessary factors and general tendencies, Ibn Khaldūn notes how cities differ in relative prosperity and levels of commercial activity, and identifies a general explanation: population size. Unlike modern Malthusian understandings, however, population is not an isolated factor determining resource competition and so on, but rather indicates the source of all wealth, human labour. As Ibn Khaldūn presciently writes, "human labour is necessary for every profit and capital accumulation «, ${ }^{4}$ and in cities with large populations "combined labour produces more than the needs and necessities of the workers «. ${ }^{5}$ This leads to rising commercial activity and a coeval increase in the city's total income and expenditure. So the political regime extracts commercial taxes, supporting its own further expansion and augmenting general taxation on land and households, which Ibn Khaldūn claims tend towards falling rates of return over a state system's lifetime. ${ }^{6}$ Yet commercial taxation presents inherent dangers: prices and living costs increase, and expenditures grow faster than incomes, steadily immiserating citizens so that the population declines. Eventually:

...when the [available] labour is all gone or decreases because of a decrease in civilization, God permits profits to be abolished. Cities with few inhabitants can be observed to offer little sustenance and profit, or none whatever, because little human labour [is available]...This goes so far that even the flow of springs and rivers stops in waste areas. Springs flow only if they are dug out and the water drawn. This requires human labour...This can be observed in countries where springs existed in the days of their civilization. Then, they fell into ruins, and the water of the springs disappeared completely in the ground, as if it had never existed. ${ }^{7}$

Ibn Khaldūn, Muqaddimah, 263-295. Cf. Banaji, Theory, 263-264; I must thank Jairus Banaji for drawing my attention to these sections' relevance to this article. On Ibn Khaldūn generally, see Lacoste, Ibn Khaldun.

2 His term dawla is often translated as »dynasty«, but this has misleading connotations.

Ibn Khaldūn, Muqaddimah, 264-265.

4 The term for capital is mal, generally »wealth« but also capital in the specific sense; see Ibn Khaldūn, Muqaddimah, 298; and Banaji, Theory, 263-264. On labour theories of value generally, see Graeber, Towards an Anthropological Theory of Value.

5 Ibn Khaldūn, Muqaddimah, 273.

6 Ibn Khaldūn, Muqaddimah, 230-232.

7 Ibn Khaldūn, Muqaddimah, 299. 
This article focuses on one such urbanisation, the city of Ani in central south Caucasia, a now abandoned centre straddling the Akhurian River which today marks the border between the republics of Turkey and Armenia. The timeframe is Ani's final developmental arc c.12001350 , closing in Ibn Khaldūn's lifetime. ${ }^{8}$ I explore the same themes as that early proponent of globalising social history: the preconditions, dynamics and tendencies of (de)urbanisation. In particular I explore the internal relationship between tax-based political regimes and urban elite classes accumulating through commerce, as well as the reliance of both on value produced by the labour of subaltern classes. ${ }^{9}$ This value was extracted, circulated and realised in two inextricable but mutually antagonistic forms, which together constitute the crucial combined agency in urbanisation: tax and capital. ${ }^{10}$ In Ani this contradictory symbiosis played out to the city's eventual deurbanisation, in dynamics strikingly close to Ibn Khaldūn's general model.

Ani emerged in the second half of the tenth century as part of a constellation of cities rapidly developing on the Shirak plain and across Caucasia. Dynamic urbanisation continued up to and across the thirteenth century, ${ }^{11}$ but in the fourteenth, crisis hit: by c.1350 the city's urbanising process had come to an end, beginning an afterlife as an administrative centre and more or less abandoned over the fifteenth century. I situate Ani's trajectory in a globalhistorical macro-conjuncture termed the long thirteenth century, lasting roughly 1200 to 1350. ${ }^{12}$ In a 2015 monograph Alexander Anievas and Kerem Nisancioglu emphasised the importance of Mongol hegemony across Eurasia for the long-term emergence of capitalist modernity. ${ }^{13}$ Mongol hegemony defines the long thirteenth century as a political-economic conjuncture, its end coinciding with Latin Christendom's late-medieval crisis, which engendered both economic dislocation and political turbulence, especially seen in subaltern revolts across the fourteenth, fifteenth and into the early sixteenth centuries. Likewise, the end of the long thirteenth century sees Ani's terminal deurbanisation, leaving it practically

8 All above ground remains lie on a plateau on the current Turkish side, traditionally understood as the city as such, but thereby excluding unexcavated suburban areas currently lying on the Armenian side. For overviews of the city's history and archaeology, see Marr, Rêve d'Arménie; Sinclair, Eastern Turkey, 356-377; Cowe (ed.), Ani: World Architectural Heritage; Mahé, Faucherre, Karamagarali and Dangles, L'Enceinte Urbaine d'Ani; and Hakobyan, Ani. This article is part of a larger project examining the entirety of Ani's trajectory, currently titled "The Fate of Unjust Cities«: Merchant Capitalism, Global History \& the Abandoned City of Ani, 90o-140o.

9 Subaltern is used in this paper in a simple sense, referring to all those subordinated to a given political-economic order, and exploitatively dominated for its reproduction.

10 In this case specifically merchant capital; see Banaji, Theory, 251-276 and Bernstein, Class Dynamics, 32-35.

11 Greenwood, Emergence, 52-55 and Sinclair, Trade, Administration, and Cities.

12 Conjuncture refers to the way in which social, political and economic dynamics come together into a particular constellation in a given set of times and places, demonstrating a level of historical coherence and specificity. A "macro-«conjuncture is such a definable period stretching across a century or more, while a »micro-«conjuncture lasts only a couple of decades.

13 The work forms a crucial intervention in Marxism's "transition debate«; see Anievas and Nisancioglu, How the West, 64-90. On longer histories of a specifically commercial capitalism, see Banaji, Theory, 251-276 and idem, A Brief History. Hegemony refers to a relationship state of generalised social, political and/or economic dominance, so that a given state system or class "sets the rules « for other actors in a given sphere. This generalised rule-setting can refer to the regime of accumulation, the political regime, social and cultural norms, or the world system as a whole, all of which are referred to at different points in this article. Hegemony is distinct from, albeit related to, more direct rule/governance and domination. 
insignificant by the end of the fourteenth century, and the end of the Shirak plain's urban character, which more or less disappeared by the early sixteenth century. ${ }^{14}$ In her 1989 classic, Before European Hegemony, Janet Abu-Lughod similarly argued for the emergence of a nascent global political economy in the period c.1250-1350, which constituted a distinct "world system " ${ }^{15}$ This system, she proposed, formed out of longer-term processes stretching back to the tenth century, is seen in the rapid growth of cities and increasing prominence of merchants across Eurasia, from China to the Mediterranean and the Atlantic littoral. ${ }^{16}$

In this article Commercial Revolution refers to global-historical processes lasting between the tenth and fourteenth centuries, including the Mediterranean and European phenomena normally referred to as such, and stretching across Eurasia to encompass China's contemporary "medieval economic revolution ${ }^{17}{ }^{17}$ The long thirteenth century forms the apogee of these longer-term developments, a period of quantitative to qualitative shifts in short- (regional), medium- (interregional) and long-distance (intercontinental) commercial nexuses, between increasingly complex divisions of production, appropriation and distribution within, between and across different constituent regions of the world system. Mongol hegemony over the Eurasian regions of this world system constitutes the most decisive qualitative shift, forming the Commercial Revolution's political realisation across its central Eurasian expression, the medieval Silk Road. The end of this political realisation coincides with the end of the Commercial Revolution, and the start of a series of interconnecting crises and struggles out of which capitalist modernity would eventually coalesce in the sixteenth and seventeenth centuries. ${ }^{18}$ Ani's dynamic urbanisation and drastic deurbanisation forms a constituent part of these global-historical processes.

Many historiographical fields note the coincidence between the end of Mongol Eurasian hegemony and the beginning of profound political and economic crises. Specific narratives vary in their details, but the general metanarrative is that "trade " had already been increasing for two centuries or so, travelling along "arteries " around which cities grew. By uniting most of Eurasia under one political authority, the empire of the Great Khans provided the necessary "peace " for this "trade« to develop further, reaching its height in the thirteenth and early fourteenth centuries - especially in luxury commodities moving to Europe along the Silk Road. ${ }^{19}$ With the so-called Pax Mongolica's end, however, »instability « meant that arteries dried up or moved, and so »trade« and cities »declined ${ }^{20}$ Abu-Lughod, Before European Hegemony. Here I adopt the de-hyphenated "world system « to assert a continuous global development of interlocking state systems over the long term; see Frank and Gills (eds.), World System.

16 Abu-Lughod, Before European Hegemony, 357.

17 On China's "medieval economic revolution«, see classically Shiba, Commerce and Society in Sung China; the entry at Oxford Bibliographies, www.oxfordbibliographies.com/view/document/obo-9780199920082/ obo-9780199920082-0020.xml, accessed 17/04/2020; and Zhang, The River, the Plain, and the State, 86. For the Indian Ocean, see Beaujard, Globalization during the Song and Mongol Periods. On the empire of New Rome, see Patlagean, Byzance et les Marchés du Grand Commerce; and for the Mediterranean and western Europe, see classically Lopez, Commercial Revolution of the Middle Ages.

18 Cf. Wallerstein, The Modern World-System I \& II.

19 Cf. Beckwith, Empires of the Silk Road, 183-203.

20 This metanarrative is found more or less across the board, including Anievas and Nisancioglu, How the West, 7377; Abu-Lughod, Before European Hegemony, 355-356; Mutafian, Ani After Ani, 161-162; Sinclair, Trade, Administration, and Cities, 172-187; and Manandian, Trade and Cities, 189. 
Such arguments appear in regionally specific scholarship both for the period in general and in the specific case of Ani, particularly H. A. Manandian's discipline-defining monograph, The Trade and Cities of Armenia in Relation to Ancient World Trade. ${ }^{21}$ Manandian argues that Ani and the other cities of the Shirak plain developed from merchants exercising an auxiliary role in "transit trade«, profiting from the appropriation, transport and further distribution of luxury commodities whose processes of production they did not control. ${ }^{22}$ Ani and the other cities of the Shirak plain are situated in an area where Mediterranean and Middle Eastern nexuses meet and intermingle with Central Asian ones, positioned on the pre-eminent south Caucasian route connecting Iran and Central Asia to Anatolia and the Black Sea in the tenth to later thirteenth centuries. ${ }^{23}$ According to the argument's logic, if another "artery " became dominant, as happened in the later thirteenth and early fourteenth centuries, Ani's de-urbanisation would become inevitable. Manandian and, more recently, Thomas A. Sinclair have argued exactly that, seeing the end of »intercontinental trade« as definitive for Ani's end in Manandian's case, and as a fundamental shift in the city's function in Sinclair's. ${ }^{24}$ Both scholars note that Mongol taxation apparently weighed heavily on the city in the later thirteenth century, an argument often used to bolster an understanding of Mongol rule as a disaster, but, noting the city's vibrancy up to the end of the thirteenth century and relative continuation in the fourteenth, ultimately both see shifting long-distance commerce as decisive. ${ }^{25}$

Medium- and long-distance commercial exchange was undeniably central to the political economy in both the region and period in general, and Ani's development in particular - the rapid proliferation of caravanserais in twelfth- and thirteenth-century Anatolia, Upper Mesopotamia and Caucasia speaks for itself. ${ }^{26}$ But overemphasis on luxury commodity circulation, especially conceived as "trade« in the abstract, obscures the local regimes of accumulation which necessarily developed integrally to interregional and intercontinental nexuses, losing sight of the source of value in human labour as Ibn Khaldūn asserts. ${ }^{27}$ Urbanisation becomes a question of "external « factors, the presence or absence of "arteries", without any role for the local organs and musculature through which they pass. Merchants simply arrive and leave with almost naturalised commercial fluctuations, and subaltern actors simply follow

21 Manandian, Trade and Cities, 173-202.

22 Manandian, Trade and Cities, 187. Such cities are termed entrepot in Abu-Lughod, and spring up across Eurasia in the Commercial Revolution; see Before European Hegemony, 153.

23 Sinclair, Trade, Administration, and Cities, 172-179; idem, Eastern Trade, 47-48.

24 Sinclair argues more specifically for a much-reduced commercial role, and a newly emergent administrative one, with Ani's definitive end only appearing in the later fifteenth century; see Trade, Administration, and Cities, 199200 and idem, Eastern Trade, 75.

25 Manandian considers the evidence for heavy taxation »of the utmost value " but ultimately argues that the decline in "international commerce« proved decisive; Sinclair likewise finds the evidence for heavy Mongol taxation inconclusive, and argues that Ani only declined after 1350 with the end of »intercontinental trade«, and even then deurbanisation was arrested by the city's administrative role. See Manandian, Trade and Cities, 99; Sinclair, Trade, Administration, and Cities, 190-192.

26 Franklin, World, esp. 2-3 and eadem, Everyday Cosmopolitanisms; and Arakelyan, Kaghakner'e, 34.

27 On such processes on macro and micro scales, see Banaji, Theory, 251-332. 
after them. ${ }^{28}$ Similarly, Mongol taxation forms an alternative "external e explanation, with no explicated relationship to commercial and productive activity in the city and its environs. Thus we are presented with two explanations which require no analysis of the city itself: »international trade« and external taxation simply act upon Ani's urbanising process regardless of local elite or subaltern activity. Again, Ibn Khaldūn provides a crucial corrective in emphasising the internal relationship of labour, taxation, and mercantile costs in dynamics of population, income-expenditure and price, allowing - or not - profit-oriented production and capital accumulation. ${ }^{29}$

In this article, therefore, how Ani's urbanisation fits within the long thirteenth century as a global-historical macro-conjuncture is revealed, demonstrating the combined agency of merchant capital and taxation in (de)urbanising sites of accumulation - that is to say, cities - as well as the reliance of both on subaltern labour. The first section outlines Ani's

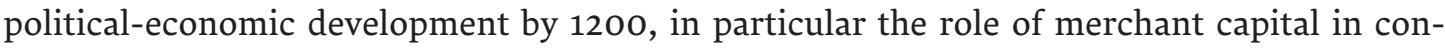
stituting the urban elite and providing it with the means to generally dominate property arrangements. The second section provides an in-depth view of Ani's development under the Georgian monarchy's pan-Caucasian hegemony (c.1190-1236), as the pre-eminent centre in the Zakarian-Mkhargrdzeli sub-polity, revealing the particular regime of accumulation in the city and its environs, the subaltern exploitation this rested on, and the class power the urban elite leveraged in order to arrange the political regime to their benefit. Finally, then, we turn to the city's trajectory under Mongol rule, lasting the remainder of the long thirteenth century, when the urban elite was integrated into a powerful state system based on extensive taxation. The conclusion summarises this story, and returns to the global-historical questions outlined here.

\section{Commerce, Land Holding and the Urban Elite by 1200}

By the outset of the long thirteenth century Ani had developed as a commercial centre for more than two centuries. The site of a fortress recorded from the seventh century, Ani rapidly urbanised from $c .950$ as a centre of the Bagratuni kingdom of Great Armenia, ${ }^{30}$ the most prominent of a constellation of commercial centres on the Shirak plain and across south Caucasia. ${ }^{31}$ In the medieval Silk Road's heyday $c .900-1300$ the Shirak plain was a region where intercontinental Mediterranean, Middle Eastern and Central Asian nexuses met, the main south Caucasian interregional nexus bringing together Anatolia, the Black Sea and northern Caucasian regions with Mesopotamia and Iran. ${ }^{32}$ Hence medium- and long-distance exchange formed the crucial vector in Ani's urbanisation from the start. The city's commercial character is clear from its initial development in the latter half of the tenth century,

28 This is implicit in most arguments, and explicit in Manandian: »we observe the drift away of the Armenian merchant population, and after it of the mass of the peasants, from Ani and the adjacent provinces«, Trade and Cities, 189.

29 Ibn Khaldūn, Muqaddimah, 231-234 and 297-299.

30 Greenwood, Emergence, 52-55.

31 The growth in commercial cities along these nexuses is noted in Minorsky, Studies in Caucasian History, 104-106; Manandian, Trade and Cities, 136-150; and Ter-Ghevondyan, Arab Emirates, 115 and 139-140. For the cities of the Shirak plain, see Sinclair, Trade, Administration, and Cities, 170-206.

32 On the importance of the Black Sea, see Peacock, Black Sea Trade, 65-72. For an overview of interregional intercontinental commerce, see Sinclair, Eastern Trade, 29-164. 
with aristocrats normally resident on patrimonial estates (hayrenik), in principal inalienable and constituting the majority of landholdings, found donating shops (kutpak) to religious foundations from the 990s. ${ }^{33}$ Alongside these lordly elite actors, entering the city appear more humble urban figures, elite actors who primarily reproduced themselves as merchants supplemented by small-scale property holdings, controlling vineyards, fields and gardens.

To maintain its class position, this nascent urban elite was subject to the dynamics of competition, profit and productive reinvestment to expand the commercial enterprise, the classic characteristics of capital accumulation. ${ }^{34}$ In particular they reinvested in lowering the relative cost and raising the amenability of transit through Ani compared to other entrepots; ${ }^{35}$ agriculture in the city environs, reflected in their donations of fields, orchards and gardens; and, importantly, urban production too. The exact bulk commodities which they transported through Ani, or invested in the local production of, are not immediately clear from surviving evidence, but we can safely assume that key among them were the regional textiles celebrated by Arab geographers - known to be produced in cities such as Dvin, ${ }^{36}$ another commercial centre some $250 \mathrm{~km}$ to Ani's southeast, regionally dominant up to the mid-tenth century and still significant into the mid-thirteenth. ${ }^{37}$ So value from human labour initially expended in commodity production far from Ani, augmented by the valorising labour also involved in transit, was realised and reinvested in the local regime of accumulation, driving urbanisation, and both integrating and diversifying labour processes in the locale.

Dependence on capital accumulation made the urban elite more precarious than the lords, who could leverage their property and status in the political regime to obtain advantage within the city's regime of accumulation, buying up urban properties like houses and shops to extract wealth from commercial profits. ${ }^{38}$ In the mid-eleventh century, however, annexation by the empire of New Rome removed the lords from Ani and its environs, resettling

33 Greenwood, Emergence, 62; Marr, Rêve d'Arménie, 69. There is one reference to the donation of five shops in Ani already in 901, which indicates a commercial character even when the site is only a fortress; see Pogossian, Foundation, 213. Ceramics is on the nexuses meeting in the Shirak plain and Ani, see: Franklin, World, 18.

34 Cf. Bernstein, Class Dynamics, 25-27. In Marxian terms this is characterised in the formula M-C-M', the use of money to buy commodities to make more money: the basic circuit of capital's expanded reproduction. Hence elite actors who reproduce themselves on this basis are in a literal sense capitalists, although depending on their patterns of investment and class reproduction they are often merchant and/or finance as opposed to industrial capitalists. In short, commercial activity can never be reduced to simplistic visions of »truck and barter«. For an alternative characterisation of such processes as "money-begetting", see Milios, Origins of Capitalism as a Social System , 97-128.

35 For example in the construction of bridges like that across the Akhurian in the later tenth century.

36 Al-Muqaddasī, The Best Divisions for Knowledge, 331-339.

37 Soviet Armenian historians such as Babayan and Arakelyan have done much to reveal the development of commodity production and widespread commercial activity in the cities of Upper Mesopotamia and Caucasia from the late ninth to thirteenth centuries, particularly drawing on ceramic evidence. Arakelyan argues for a developing division of labour in artisanal production alongside a proliferation of commercial organisation, and a consequent decoupling and then subordination of agricultural production to urban commercial dynamics. Most importantly, this is explicitly seen as part of a broader development in caravan routes and developments in production and exchange on both a regional and global scale; see Arakelyan, Kaghakner'e, vols. 1-2, esp. vol. 2, 16 and 34; and Babayan, Zakarid power, 554.

38 The aristocratic Pahlavuni family are a particularly clear example; see Divan, ed. Orbeli, 94 and 95:32. 
them on estates further west and transforming their lands into imperial estates. ${ }^{39}$ Ani's urban elite remained, negotiating with the imperial centre to take over the city's administration, obtaining East Roman titles and taking on key state roles such as maintaining the garrison, gaining tax reductions and exemptions in return..$^{40}$ Importantly, these include lowering the market tax alongside specific attempts to reduce the costs of commerce, lowering the »cart « or transit tax for everyone entering the city, and abolishing the levy entirely for Ani-based merchants as well as halving the levy on their buying and selling cotton. ${ }^{41}$ The image emerges of a sub-imperial oligarchy run by a self-conscious urban elite heavily concerned with commodity transit and commercial exchange, including of locally produced cotton and potentially also processed textiles, ${ }^{42}$ leveraging their class power to arrange taxation to the benefit of capital accumulation. Contemporary Greek histories written by imperial officials describe Ani's governing elite as merchants and note the numerous villages in the city's environs, as well as luxury commodities coming to Caucasian cities from far-away lands like India and China. ${ }^{43}$

Roman rule formed a crucial micro-conjuncture in Ani's overall trajectory, seeing the aristocratic lords' removal and forging an urban polity with its own elite conscious of their own interests, especially the profitability of commercial transit and exchange. Their oligarchy came to an end with the city's conquest by the Seljuq in 1064 and subsequent purchase in 1072 by a scion of the Kurdish Shaddadid amirs of Dvin - which in itself indicates the importance of a merchant-led cash economy, from which the ruling family profited first in Dvin, and then in Ani. ${ }^{44}$ The empire's retreat poses the question of what happened to aristocratic hayrenik' transformed into imperial demesnes. Unfortunately the evidence for landholding, primarily donor inscriptions to religious institutions, more or less dries up in the later eleventh and twelfth centuries. Yet urban revolts in 1124, 1156 and 1161 indicate a politically self-conscious elite reluctant to see their class power contained, resulting in changes of rulership either between Shaddadid amirs, or from Shaddadid to Georgian rule. ${ }^{45}$ The sole surviving twelfth-century inscription from the city walls proves suggestive:

In the year 1160 in the reign of Fadlan, and the patriarchate of Lord Barsegh, I Abraham built this tower (burj) from my halal silver in memory of me and my parents. Let whoever reads [this] remember in their prayers me and my parents and the teacher who was sent (zarak'eal vardapet). ${ }^{46}$

39 Some estates transformed into ecclesiastical domains, but the comprehensive absence of the aristocratic elite after 1045 is striking. Skylitzes, Synopsis, 409-412. Following recent revisionist arguments I have adopted the nomenclature »Empire of New Rome« and »(East) Roman" for the state system normally termed »Byzantium" and »Byzantine«; see Kaldellis, Romanland.

40 This is revealed in two inscriptions, one of 1056 and another of 1059, as well as a narrative section in Michael Attaleiates' history which aligns perfectly with the latter; see Attaleiates, History, 145-151; Divan, ed. Orbeli, 106:37 and 107:38.

41 Divan, ed. Orbeli, 107:38.

42 On the general importance of cotton, see Beckert, Empire of Cotton, esp. 3-28.

43 Attaleiates, History, 147, 149 and 271; and Skylitzes, Synopsis, 409-412 and 423-424.

44 On the Shaddadids, see Ter-Ghevondyan, Arab Emirates, 119-124; Minorsky, Studies, 1-101; Marr, Rêve d'Arménie, 67; and Manandian, Trade and Cities, 179-180. For an overview of Dvin's urban constellation and archaeology, see Babajanyan, Medieval Urban System, 327-344.

$45 K^{\prime}$ art'lis C'xovreba, ed. Jones et al., 350.

46 Divan, ed. Orbeli, 4:2. The reading "teacher who was sent « could alternatively be rendered as a proper name and title, »the Vardapet Arakeal«, however this seems an unlikely specification in a donor inscription of this type, and instead has here been read as an ambiguous religious formula referring to Christ. 
This dates to the reign of Faḍlūn ibn Muhammad, who replaced his brother as amir following the 1156 revolt, and was himself replaced by royal Georgian rule in 1161. The inscription follows standard Armenian epigraphic practice, adopting the benefactor's voice in an emphatic first person, but the amir's lack of titles and honorifics is notable: Abraham's action is recorded for posterity with no agency attributed to the ruler. Crucially, Abraham himself lists no surname or title, and notes that the tower was constructed from his »halal« silver, a technical term in medieval Armenian epigraphy indicating property gained by financial and commercial means, here specifically money. ${ }^{47}$ Abraham takes on a key function normally fulfilled by ruling elite classes, requiring a significant outlay of wealth and indicating the class power Ani's mid-twelfth-century elite could leverage from capital accumulation. The final testament to Shaddadid rule is a bilingual Persian-Armenian mosque inscription, which stipulates a market area from »the mosque of Abul-Mamaran to the shop on Sebil street ${ }^{48}$ Importantly, this market is explicitly for "the sale of cotton and cotton objects", indicating both raw cotton and processed textiles, ${ }^{49}$ the same commodities on which Ani's elite had lowered transit taxes a century and a half earlier. Cotton thus continued to form a primary commodity within the city and its environs, with the Shaddadid amirs attempting to regulate and tax its sale effectively, ordering "trade to take place in this very spot «.

So the urban elite's prominence and commercial character is clear, but what about land holding $?^{50}$ The corpus of donor inscriptions at Horomos Monastery, founded in the early tenth century $40 \mathrm{~km}$ north of Ani, provides a useful measure for elite composition and property arrangements across the city's developmental trajectory. ${ }^{51}$ No dated donations survive before the twelfth-century's final years, with the single exception of a vineyard granted in $1174 .^{52}$ When they reappear regularly from 1197 , the donors are exclusively non-aristocratic elite actors - the sole earlier twelfth-century inscription is also the sole exception, the relatively humble gift of a certain priest, Petros, and his nephews, the azats (lords, lit. "freemen «) Yusik and Simeon. After this point, however, no donor is identified as an azat or any other aristocratic title, and none celebrate their noble descent in the manner of Ani's earlier aristocratic donations and elsewhere contemporaneously - a rule that holds at Horomos

47 Abraham's name and ambiguous religious formula raises the question of ethnic and religious identifications. Epigraphic evidence from Armenian churches necessarily only reveals Armenian Christians, but Arabic names and administrative titles indicate the situation of Ani's elite in a Middle Eastern mercantile world dominated by Arabicspeaking Muslims. Especially in the twelfth century, there must have been Muslim merchants resident in Ani, but no positive evidence survives. Nevertheless, the use of the term halāl indicates the extent to which Islamic legal and cultural codes were common to Christian Armenians, especially with regard to wealth accumulation. For a source on Muslim presence in twelfth-century Ani, see Peacock, Interfaith Polemic; and cf. La Porta, Reconstructing Armenia.

48 See Minorsky, Studies, 100-101 and Manandian, Trade and Cities, 181.

49 For indications of processed and decorated textiles reflected in Ani's architecture, see Lessing, Silk Road without Fabrics, 155-181.

50 For Ibn Khaldūn's analysis of urban merchants' accumulation of extra-mural estates, see Muqadimmah, 280-281.

51 The Horomos monastery is extremely important for the city of Ani, sitting in its environs and reflecting the city's development from a royal Bagratuni site into a commercial centre dominated by the urban elite. For the monastery, see Vardanyan (ed.), Horomos; for the inscriptions in particular, see Horomos inscriptions, ed. Karapetyan and Mahé; see also Sinclair, Eastern Turkey, 378-384.

52 Horomos inscriptions, ed. Karapetyan and Mahé, 29:429. 
to the end of the long thirteenth century. Instead some list their fathers and grandfathers without hyperbole, some their places of origin, and many simply their first names alone, with a handful using titles from the urban administration such as hečup (»chancellor", Arab. häjib originally »chamberlain«) and »amir« (»lord mayor«, Arab. »ruler«) - there is even one instance mirroring Islamic paedonymy, when in 1201 the hečup Grigor described himself as "father of Amir Ḥasan«. .3

Two early emblematic examples from Horomos are an undated piece from the later twelfth century where a certain Yohanes gave half the village of Seghank and a certain Paron half of the village of Mashkakap, ${ }^{54}$ and another of 1197 in which a certain Smbat gave half of a village named Marants Marg. ${ }^{55}$ These represent instances of a novel phenomenon: the division of villages into shares which could then be bought, sold and donated as distinct units of property. These shares gave rights to a portion of the village's income in cash (dang) rather than the land itself, and originated in inheritance practices among Ani's urban elite introduced to a novel sphere, ${ }^{56}$ village rents - seemingly the fate of the "many villages « Roman historians note in Ani's environs. ${ }^{57}$ Importantly, chapters 101-104 of Mkhitar Gosh's Lawcode, written in 1184, provide precepts on inheritance explicitly framed as the division of incomes into fractions of monetary value..$^{58}$ Mkhitar was a peripatetic monastic teacher or vardapet who became prominent under the Zakarian-Mkhargrdzeli, and ended his days in 1213 at the restored Nor Getik Monastery, eponymously renamed Goshavank, ‘Gosh's Monastery ${ }^{59}{ }^{5}$ The Lawcode was composed in 1184, particularly in order to provide Armenian Christians with their own law and so avoid Islamic courts. Its statutes are consciously and critically compiled from biblical and canon law, the early twelfth century penitential attributed to Davit of Ganja, and, most importantly, Mkhitar's own experience of legal customs gained from wide travels across Caucasia, Upper Mesopotamia, northern Syria and Cilicia. So the composition is prescriptive and normative, like all legal texts, but also in active dialogue with customary practice's general principles and regional differences, attempting to synthesise these into a coherent body while allowing for practical variation. Putting together its precepts with the dynamics of rentier and merchant capitalist accumulation, it becomes possible to critically imagine otherwise under-sourced or unknown aspects of political economy in Ani and its environs.

53 Horomos inscriptions, ed. Karapetyan and Mahé, 31:430-431 and 21:421-422.

54 Horomos inscriptions, ed. Karapetyan and Mahé, 39:439.

55 Horomos inscriptions, ed. Karapetyan and Mahé, 38:438.

56 These practices are closely related to Islamic waqf/waqfiyya; see Peacock, Waqf Inscriptions, 183-193; Trépanier, Foodways, 9 and 142-145.

57 Attaleiates, History, 147.

58 The Lawcode is an under-utilised source for Armenian social history in the central Middle Ages, and although it is not known where it was composed, or if there was a specific patron, it is essential to include it in social and political-economic analyses. Nevertheless, there is an urgent need for further scholarship, especially of the manuscript tradition, especially to establish whether its precepts can be more precisely geographically situated than is possible simply by listing Mkhitar's travels. See the introduction to Gosh, Lawcode, trans. Thomson; and for the precepts on inheritance, see pages 181-188.

59 Gosh, Lawcode, trans. Thomson, 11-39. 
In Mkhitar's "rules of division « the whole property is reckoned as one dahekan, literally a gold coin but here denoting the whole of a given income, which can then be subdivided into six dang, the name for subsidiary electrum coins which formed a central medium for commercial exchange. ${ }^{60}$ The precepts then delineate various divisions in different circumstances, for example that "the brother who is not from the same mother will inherit half a dang less than those [who share their mother] «. Thus an individual actor's rights to a given village's rents were subdivided among heirs and pious donations, over time producing a system of fractional shares which could be bought, sold, and redivided for donation and inheritance. This is mirrored by fractional shares of income from means of production such as mills, and indeed rights to all or a portion of the incomes from a given village's water sources, mills and other means were often bought and sold separately to the village shares as such. Payments were in principle cash rents, but the right was claimed over all income, a comprehensiveness implied in the formula »soil and water ${ }^{61}$

By 1200 , therefore, property arrangements in Ani and its environs had been utterly transformed from the period of lordly dominance. Villages had become social units of production corporately exploited through cash rents by various elite actors and institutions, including both religious and commercial foundations such as caravanserais. ${ }^{62}$ Tellingly, by the later twelfth century hayrenik' refers not to inalienable aristocratic patrimony but to any property which the owner could dispose of freely as their own, movable as well as immovable, and including diverse landholdings, cash and shares of villages, mills and other means of production. ${ }^{63}$ So in a 1201 donation to Horomos, a certain Khacheghbayr and his son Avetis describe one-sixth of the incomes of Marants Marg as their hayrenik', ${ }^{64}$ while in another of 1231, Aslan son of Sheranik and his wife Asushah gave hayrenik' which they had »bought with money, a twelfth of the income (dang) of Godis, soil and water «. ${ }^{65}$ As Kathryn Franklin aptly notes, "the concept of princely rights was being expanded to accommodate not just a new kind of wealth but a new kind of prince. ${ }^{66}$

60 Dang could then be further subdivided into four silver t'asu, and twelve copper gari; see Gosh, Lawcode, trans. Thomson, 187. These fractional divisions are given a striking Christian numerology in chapter 250, culminating in the statement: »The dram (coin) is the mystery of our nature, because its letters [spell] >man< (mard) in reverse order«; see Gosh, Lawcode, trans. Thomson, 303-304.

61 Issues of water rights separate to rights over land begin to appear from the mid-ninth century in Armenian inscriptions.

62 Cf. Trépanier, Foodways, 31-32.

63 Bedrosian, Turco-Mongol Invasions, 162; Horomos inscriptions, ed. Karapetyan and Mahé, 369; Babayan, Zakarid power, 555; La Porta, Reconstructing Armenia, 259.

64 Horomos inscriptions, ed. Karapetyan and Mahé, 41:441.

65 Horomos inscriptions, ed. Karapetyan and Mahé, 22:424.

66 Franklin, World, 86. 
Ani in the Zakarian-Mkhargrdzeli Regime, c.120o-1236

At the outset of the long thirteenth century, therefore, two points are clear: the first is that Ani was a wealthy commercial city, with a self-conscious urban elite involved in mediumand long-distance exchange as well as local auxiliary commodity circuits; ${ }^{67}$ and the second is that, when the veil is lifted on property arrangements in Ani and its environs in the early thirteenth century, the urban elite is self-evidently hegemonic in local political economy. Importantly, therefore, this predates the 1198/1199 Zakarian-Mkhargrdzeli conquest, and so forms a pre-existing factor in Ani's integration into the emerging political regime. Established in a series of conquests across the 1190 s by the Kurdish-descended Armenian generals Zakare and Ivane ${ }^{68}$ and a constituent part of the Georgian kingdom then hegemonic across Caucasia, Ani formed this regime's most important urban centre between $c .1200$ and 1236. The family continued to govern the city under Mongol and Ilkhanate rule until c.1320, almost throughout the long thirteenth century, albeit articulated under two very different hegemonic state systems. The first is a sub-polity within the broader Georgian kingdom, the exact characteristics of which remain obscured by »feudal« assumptions. ${ }^{69}$

The Zakarian-Mkhargrdzeli regime's political articulation is returned to at the end of this section, both in Ani and beyond. For the moment the important point is that the urban elite's hegemony over property arrangements in Ani, and so over the regime of accumulation, is not a result of land grants from the new rulers, as happened in other newly conquered regions. Instead, between the later eleventh and later twelfth centuries Ani's urban elite reinvested capital accumulated from medium- and long-distance commerce in buying the rights to village rents, either an inherited share or as a whole, and did the same with other means of production like mills and waterways. In such manner the urban elite made their position less immediately dependent on commercial profits, and so more secure in the first instance, but simultaneously integrated village rentierism into a regime of accumulation still defined by medium- and long-distance exchange. In this dialectical movement a factor appearing external in one moment, interregional and intercontinental commerce, appears internal the next, capital invested rents and in local commodity production. Local capital investment then dictates in turn the dynamics of interregional and intercontinental commerce as this passes through the local regime of accumulation, once again becoming "externalised».

67 For the various commodities produced and exchanged in regional cities up to the mid-eleventh century, especially Dvin, see Ter-Ghevondyan, Arab Emirates, 137-142.

68 The family itself perfectly expresses the complex identifications of Upper Mesopotamia and Caucasia's elite class. Ivane and Zakare, sons of Sargis Mkhargrdzeli, who brought the family to prominence in the second half of the twelfth century, are claimed to descend from a Mesopotamian Kurd of the »Babirakan xel « (Kurd. gel, »tribe/ people«), who in the eleventh century entered first the service of the Armenian kings of Lori-Tashir and then the Georgian monarchs. The family converted from Islam to the independent Armenian Church, and in the early thirteenth century Ivane converted to Georgian Orthodoxy. The family's first connection to Ani came with the Georgian takeover of 1161, when Sargis assisted the new governor-general, and then briefly governed himself during a short occupation 1174-1175. See Minorsky, Studies, 101-103. For an analysis of the Zakarian-Mkhargrdzeli regime's political articulation of Armenianness, see La Porta, Reconstructing Armenia, 251-272. For the Georgian kingdom in this period, see Rayfield, Edge of Empires, 111-117.

69 For example in Bedrosian, Seljuk and Mongol periods, 253-255; idem, Turco-Mongol Invasions, 157; Babayan, Zakarid Power; and Mutafian, Ani After Ani, 159-160. 
The wealth urban elite actors could achieve through this merchant-rentier regime of accumulation is demonstrated in Ani's most famous inscription: Tigran Honents' founding 1215 donation to his new church of St. Grigor, built by the banks of the Akhurian on land "bought by me from the owners with halal hayrenik " $"{ }^{70}$ In this lengthy piece, Tigran enumerates the many and various properties donated: half the rents of three villages, one with five dangs from the village stone quarry, all the rents of a different village, and two dangs of the rents of yet another. In addition to village rents, he grants one "hostelry-funduq« in the city; a private bath with its waterworks »in the square«; a hostelry-xanapar with shops; another hostelry-funduq "with the new vaulted roof «; a bathhouse and ante-chamber; stables, barns and a threshing floor »bought by me«; an oil press with two wheels; more stables and barns and a threshing-floor »bought by me«; a vegetable garden by the river »laid out by me«; half the income of a mill situated by the Dvin gate with full control over the process of milling, as well as two days of milling rights per week at two other mills; "half the river bought by me between Beshkenakap and the bridge«; four dangs of the hostelry-xanapar called Papents as well as "the shop by its door «; all the houses on Hatestonts street; "many lots of land bought near the city gates «; a garden in each of Yerivan, Oshakan, Kos, Aruch, Mren and Chmak; and, finally, "many more lands, which are in mortgage" not listed in the act but donated nonetheless, to be returned to the debtors »if they pay gold to the monastery «.

Considering this donation necessarily forms only part of Tigran's total wealth, the level is astounding. He is the most impressive surviving example of the so-called mecatun, a contemporary identifier for urban elite classes literally meaning the "great housed " $^{71}-$ and, indeed, Tigran's own residence, often identified with the so-called merchant's palace, ${ }^{72}$ is mentioned for orientation in a 1218 donation to Horomos, granting "the shop which I had bought with a wine cellar below in Ani, in the upper part of the mains street, close enough to Tigran's house ${ }^{73}$ His foundation inscription reveals the infrastructure both built and monopolised by Ani's urban elite. The sheer range indicates the extent of the merchant-rentiers' hegemony over the city's regime of accumulation, their generalised, rule-setting dominance in configurations of production, appropriation and distribution, directing these towards the reproduction of their class. On the one hand, this regime of accumulation was defined by profit from medium- and long-distance exchange, and Tigran donates no less than four hostelries, two funduqs for merchants transporting large-scale commodity stocks, and two xanapars for individual travellers and merchants without large stocks, both of which came with shops attached - that is, comprehensive warehouse-cum-hostel and office complexes for commercial activity. ${ }^{74}$ On the other hand, the regime of accumulation relied on rents,

70 Divan, ed. Orbeli, 188:62-63; a more or less complete English translation can be found in Manandian, Trade and Cities, 185-186.

71 Bedrosian erroneously refers to the mecatun as "nobility«; see Seljuk and Mongol periods, 254-255. See also Babayan, Zakarid power, 547.

72 Marr, Reve d'Ani, 123-125.

73 Horomos inscriptions, ed. Karapetyan and Mahé, 43:443.

74 On these property types, see Horomos inscriptions, ed. Karapetyan and Mahé, 373; for the archaeological remains, see Marr, Reve d'Ani, 133-135. Also see generally Concina, Fondaci and Constable, Housing the Stranger. 
and Tigran grants a diverse range of properties with various potential subsidiary uses in production and exchange, including bath houses and waterworks, travel infrastructure, various production installations, agricultural lands, houses, shops - even sections of the Akhurian River have been privatised. Alongside merchant capital and rents, Ani's urban elite accumulated through credit and debt, finance capital, and the donation of mortgaged but redeemable lands to a religious institution indicates the circulation of capitalised property. ${ }^{75}$ Finally, Tigran controls several village incomes, including several properties relatively far from Ani, for example »the village of Khazats-Mahmund in the land of Kars«. This indicates merchant capital's extra-urban reach through the urban elite's rentierism, integrating further regions into a regime of accumulation defined by medium- and long-distance commerce.

But what of the role of human labour in generating the value realised in Ani's urbanisation, in the spirit of Ibn Khaldūn's model? Of course, merchant capital often realises the value congealed in a commodity far from the place where this labour was carried out, augmented by the labour involved in transportation, storage and so on, but subaltern labour is also essential to the local merchant-rentier regime of accumulation. In the first instance it is clear that this necessarily rested on the widespread exploitation of subaltern labour through cash demands, necessitating in turn widespread monetisation of social relations. Village rents formed the central demands, and these in turn would compel subaltern actors to take on debts and commodify produce to obtain coin for payment - could control of village rents sometimes be collected in commodifiable produce, or even translate into control over immediate processes of commodity production $?^{76}$ Similarly, the processes of production that developed to support and supply commercial infrastructure, especially the many caravanserais, xans and funduqs, obviously involved subaltern labour and exploitation. The same goes for the production and transit of cotton, a classic cash crop developed for commercial exchange, as well as processed textiles most likely organised in urban workshops but potentially also through a >putting-out system< in surrounding villages. ${ }^{.7}$ All this would indicate the extent of subaltern labour's integration into a regime of accumulation defined by commercial exchange. ${ }^{78}$

Frustratingly, however, subaltern actors themselves are entirely absent from inscriptions and documents. Property rights are articulated over the income of a village or productive installation, either a share or as a whole, and labour dues may also be implied by the phrase "soil and water", but the actual subaltern actor's responsibilities are never mentioned. Much the same picture is presented by references to urban millstones and production installations, as well as their archaeological remains today, including bakeries, wineries and linseed oil workshops, which occasionally include well-preserved large grindstones. All such installations, of course, required now entirely obscure subaltern labour. ${ }^{79}$ Urban production involved divisions of artisanal labour and commodity production, indicated by inscriptional references to, 
for example, »the street of the blacksmith ${ }^{80}{ }^{80}$ »the street of the shoemakers«, »the street of the smiths" and the "street of the saddlemakers « ${ }^{81}$ areas of the city dedicated to a particular craft industry and divided into a central street ( $p^{\prime}$ otoc $^{\circ}$ ) and adjacent alleys (zukak). One donor to Horomos in 1231 names himself Kotit the fur tailor and donates one sixth of the income of Zov village, "soil and water $"{ }^{82}$ indicating that some artisans accumulated enough capital from commodity production, that is, industrial capital, to reinvest and transform themselves into merchant-rentiers, and this no doubt involved coordinated labour on a relative scale. Archaeological finds indicate the production and exchange of ceramics, glass, bronze ware, processed textiles and presumably also the primary commodities that went into their production like metals, raw cloth and dye materials, as well as the perishable commodities transported and stored in surviving ceramics. ${ }^{83}$ All these formed auxiliary small- and medium-distance commodity circuits based on local subaltern labour that developed around long-distance nexuses, with significant interregional circulation - hence the fame of "Armenian goods", textiles and their various subsidiary commodities, as well as »Armenian clay", in medieval Greek and Arabic sources. ${ }^{84}$ But, once again, nothing survives to indicate how this commodity production and the necessary labour was organised, so that the particular relations of exploitation between elite and subaltern classes remain obscure.

Evocations of the conditions of subaltern classes can, however, be found in Mkhitar's Lawcode, written at the start of the late twelfth-century conquests which resulted in the Zakarian-Mkhargrdzeli regime. The work reflects a merchant-dominated society, for example in chapter 14's assumption that husbands would often be away from their wives "because of commerce «. ${ }^{85}$ The composition's moral economy is often uncomfortable with commercial and financial accumulation, prescribing excommunication for deceit in commerce in chapter 185 - although chapter 99 does defend honest commercial profits. ${ }^{86}$ Nevertheless, in chapter 240's statutes for markets, the right to their establishment is reserved to kings and princes, with rights to control prices and raise taxes also placed in their hands, while Mkhitar attacks merchants who "deprive the poor according to the needs of merchants or the wealthy «. ${ }^{87}$ These idealistic precepts are more revealing of the composition's broader purposes, particularly constructing the potential juridical basis for a putative Armenian kingdom, than concrete realities in Ani or elsewhere in the early thirteenth century. But the city's markets were regulated and taxed: an official bearing the same title as Islamic market regulators, the muhtasib, is found collecting commercial taxes under Roman rule. A moral economy conditioned by the desire to construct a legal basis for an idealised traditional elite is particularly clear in chapter 31 on the division of village resources. ${ }^{88}$ Gold mines are granted to kings,

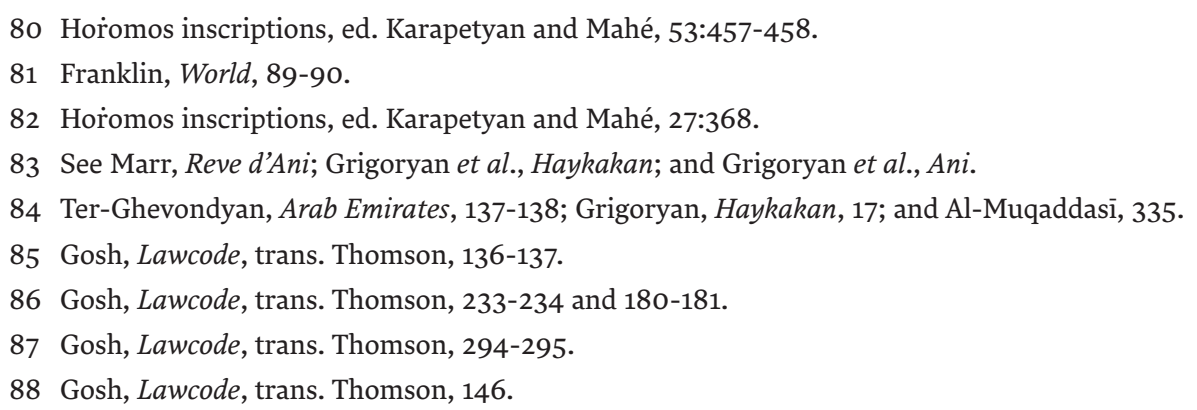


silver mines to queens, and copper and iron to princes, clearly a schematic hierarchy, but one that may speak to Mkhitar's anxiety over the extent of village integration into rentier and merchant capitalist accumulation - for example the five dangs of a stone quarry donated by Tigran. Mkhitar even hopefully grants princes the sole right over "tar and incense and yellow-incense, gall and mastic, agaric and scammony, and other such things which are traded for profit«, indicating the spectrum of commodifiable resources extracted from village units. Anxiety over this process is indicated in the chapter's insistence that subaltern actors retain foraging, timber and pasture rights in all territories, whoever owns them, indicating that these areas were often enclosed and access monetised. ${ }^{89}$

The extent of assumed wage labour is particularly striking in the Lawcode,${ }^{90} \mathrm{a}$ form of exploitation not commonly associated with medieval Caucasia, but one that performs the important function of putting coin directly into subaltern hands. In chapter 238 , for example, shepherds and herdsmen are found working for wages, the rates of which vary waccording to the custom of the provinces", detailing those situations where the worker is liable for an animal's loss and their wages can be legitimately withheld. ${ }^{91}$ Likewise, chapter 245 details the hiring of work animals, indicating that in many situations waged workers would also need to cover the costs of using these essential means of production, necessitating yet more access to coin..$^{92}$ The same is true for artisans, who might work »by the piece or for a wage « and often hire their tools, which may break in the course of their work, making the worker liable in certain situations for their replacement. Likewise Ani's elite are commonly found controlling incomes from mills, paying the miller a fee that varied by province, as detailed in chapter $44 .{ }^{93}$ The miller was a waged worker with no ownership of the actual mill, the incomes of which might be held in shares by various individual and institutional owners, often varying between different grindstones, ${ }^{94}$ all of the owners having a claim to the profits and some also having defined rights over milling for a certain number of days. In Tigran's 1215 donation, for example, he grants half the income of a mill by the Dvin gate as well as the right to full control over the milling, along with two days of milling rights at two further installations. One of these is in a village named Glijor, which apparently had at least two mills, since the income of "the middle grindstone of the mill in Glijor « had already been granted to Horomos

89 For example, in 1262 a certain Garegoyn gave a village with all its forests to the monastery of Bagnayr; see Horomos inscriptions, ed. Karapetyan and Mahé, 468-469, note 176.

90 The exact form of wage labour, whether long contracts or day labour, is not clear - both should be assumed given the varying kinds of activity indicated, from working in the vineyards to shepherding.

91 Gosh, Lawcode, trans. Thomson, 293-294.

92 Gosh, Lawcode, trans. Thomson, 299.

93 Gosh, Lawcode, trans. Thomson, 153.

94 For example the Horomos one of 1234 where Zmrukht Khatun gave "the whole of [the income] of one grindstone in the mill of Karmnzhi which is called ıof the Abeleank «, see: Horomos inscriptions, ed. Karapetyan and Mahé, 46:448-449. 
by a certain Yohannes son of Tadeos in $1197,{ }^{95}$ while Tigran also gave "my mill, that I had restored from its ruins in Glijor « to Horomos in 1201 - presumably the same installation at which his new foundation gained two days milling rights in $1215 .{ }^{96}$ Chapter 100 on the leasing of water-mills "and other such things « stipulates that the profit should »be without scruple to the lender, and let him not pay taxes on the profit", with the lender taking responsibility for maintenance and upkeep in return, although the leaser is responsible for damage from negligent use. ${ }^{97}$

So the image is one of compounding pressures from rent demands resulting in subaltern actors increasingly taking on wage labour, commodifying their productive activity and entering debt relations, as well as selling and mortgaging property to Ani's urban elite. This monetisation of social relations developed along with the privatisation and capitalisation of the property subaltern classes used, making their access to this property, the means for their self-reproduction, increasingly precarious, dependent on continued access to yet more coin. Such pressures are indicated in the Lawcode's moral-economic stance, for example noting in chapter 126 , "Statutes for hired servants in general ", that someone only becomes "a hired servant because of poverty and his day of need $",{ }^{98}$ and stipulating in chapter 237 for vineyard workers that their wages should be higher in periods of scarcity and lower in times of abundance, a reverse principle of supply and demand to support precarious workers dependent on wage labour for survival. ${ }^{99}$ Mkhitar is particularly concerned that impoverished subaltern actors who sell or pledge property as collateral for debts are able to redeem it at a reasonable price and without interest. ${ }^{100}$ Land sales must be redeemable for up to seven years if »because of poverty one sells part of one's property«, and wealthy people who have bought and sold a poor person's house should return it "for the sake of mercy«. Similarly watermills "sold because of poverty« can be redeemed by the original owner or their relatives for up to a year, and in the statutes on pledges of property as collateral, special care is taken that poor people do not pledge the "most necessary things «, such as millstones, and so remove the means for their existence. Likewise, chapter 82 on loans is at pains to avoid usury on credit extended to the poor, although interestingly it does permit interest more generally, and chapter 83 legislates that property pledged as collateral should bear no interest. ${ }^{101}$

Hence demands for cash rents subjected subaltern labour to monetised forms of exploitation that themselves gave further opportunity for Ani's urban elite to accumulate. Unfortunately the organisation of subaltern labour remains more or less obscure, although chapter 237 on "the statutes for labourers who work in vineyards « indicates that some worked in "cooperative" work gangs hired as a unit, apparently self-organised and dividing wages equitably among themselves, while others were hired individually. ${ }^{102}$ In the end, however, the

95 Horomos inscriptions, ed. Karapetyan and Mahé, 38:438.

96 Horomos inscriptions, ed. Karapetyan and Mahé, 40:440.

97 Gosh, Lawcode, trans. Thomson, 180-181.

98 Gosh, Lawcode, trans. Thomson, 200.

99 Gosh, Lawcode, trans. Thomson, 292-293.

100 Gosh, Lawcode, trans. Thomson, 176-177.

101 Gosh, Lawcode, trans. Thomson, 170-172.

102 Gosh, Lawcode, trans. Thomson, 292-293. 
chapter notes that "I am not able to describe accurately the model because of the varied customs of provinces and countries." Nevertheless subaltern classes in Ani and its environs were certainly not the homogenised peasants found in common-sense assumptions about "feudalism". Rather, they were actors choosing or finding themselves in different labour arrangements and with varying access to property ${ }^{103}$ Such varying arrangements should be imagined in chapter 99, on sthe statutes for the sellers and buyers of the fruit of vines and of other stocks", when it is noted that many landowners pre-sell the year's stock wholesale »in the hope of profit «. ${ }^{104}$ However, advance sale leaves the chance of a shortfall in the eventual crop, in which case, Mkhitar says, the seller-landowner must keep the whole principal, pushing the cost onto the would-be buyer-merchant, since the landowner would have had to pay for the workforce.

At the same time as an apparent growth in wage labour, this period sees the first evidence for the emergence of forms of unfree tenancy, notably in chapter 21 "on peasants «. ${ }^{105}$ This states that while peasants are born free, if the head of the household became a tenant, then he and all his children could be kept on the estate until his death, at which point the children were again free to go. There is no evidence for such arrangements previously, indicating the growth of forms of unfree tenancy in a conjuncture when the dual expansion of rentierism and commercial exchange engendered new pressures to raise the rate of exploitation. As Mkhitar comments, "Our human nature was created free by the Creator, but in response to the necessities of the land and the water, it gradually came to serve masters « - necessities violently materialised in demands for rent, the phrase "land and water " notably reminiscent of the epigraphic formula "soil and water«. The simultaneous generation of »free« wage labour and "unfree" tenancy is not a contradictory argument, but rather represents contradictory drives within capital accumulation to increase monetisation of social relations on the one hand, and to raise rates of exploitation on the other. ${ }^{106}$

It seems, then, that the village rents controlled by Ani's urban elite did not have a direct relationship to control over immediate processes of production within village units, but instead produced a monetising dynamic in subaltern relations - although there remain many possible configurations which would have internally related rents to commodification, including immediate processes of commodity production, requiring further research into the question, and of course, collection in kind for specific institutions like monasteries must also be taken into account. Nevertheless control of rents did not equal control of labour processes: although elite actors did control immediate processes of production for commercial exchange, for example in vineyards and presumably also cotton, this was not immediately

103 This hybridity in arrangements is to be expected in agrarian capitalist configurations, see Banaji, Theory, 336 and Bernstein, Class Dynamics, 101-114.

104 Gosh, Lawcode, trans. Thomson, 180.

105 Gosh, Lawcode, trans. Thomson, 141.

106 Just as the great age of merchant capitalism between the fifteenth and eighteenth centuries saw both the first mass wage-labour forces in western Europe, and the so-called "second serfdom " in central and eastern Europe, as well as history's largest recorded trade in chattel slaves; see Banaji, Theory, 67-102. 
related to their rights to village rents. The urban elite accumulated coin from both rents and commercial exchange, which could then be reinvested in commodity production and acquisition, as well as building projects, accumulating property and buying the rights to further village rents. This coin found its way into subaltern hands through produce commodification, wage labour, debt and property sales, although some may have preferred to take on relatively unfree agricultural tenancies instead, making the landlord liable for their contribution to the total village rent.

Such dynamics of increased exploitation and increasing impoverishment necessarily incurred subaltern resistance, counterpower.$^{107}$ Counterpower emerges from subaltern classes' attempts to autonomously organise their own lives and productive labour within, against and beyond the wide spectrum of mechanisms through which this was subjected to exploitation - from irreducible demands backed up with violence like tax and rent, to mechanisms to meet these demands like produce commodification, debt and wage labour. Every piece of property listed in Tigran's donation must be imagined as bound up with countless such moments, entirely anonymous and unrecorded. These moments, like subaltern classes themselves, must be critically imagined in their profound empirical absence, constituting historical dark matter. For example, the accumulation of counterpolitical moments must be assumed to lie behind the many revolts by Ani's elite in the twelfth century: they leveraged hegemony in the regime of accumulation to mobilise class power not as an end in itself, but to rearrange the political regime to suit their interests, especially obtaining the coercion necessary to overcome subaltern counterpower and assure continued accumulation. As Ibn Khaldūn notes, their position means that "capitalists among the inhabitants of cities need rank and protection «. ${ }^{108}$

The final question before turning to the period of Mongol rule, then, is whether and how the urban elite leveraged their hegemony over the regime of accumulation to realise class power in the Zakarian-Mkhargrdzeli regime's articulation. Certainly within Ani and its environs there is very little evidence for feudal characterisations, nor, indeed, for any dominant Zakarian-Mkhargrdzeli presence. The city was ruled by Zakare and his descendants, who held the Persian title of amirspasalar or commander-in-chief, while Ivane and his descendants ruled Dvin and held the Turkish title atabeg, denoting a vizier-like role. ${ }^{109}$ Nevertheless, inscriptions commemorating renovations of the city walls tell much the same story as Abraham's in 1161. Of the seventeen between 1207 and 1332, only four are in Zakare's name or that of his son and successor Shāhānshāh, leaving twelve from other donors, more than twothirds of the total. ${ }^{110}$ Like Abraham's these take the form of first-person donor inscriptions, recording first the benefaction, usually payment for a watchtower or burg, and then asking for the viewer's prayers, often for named family members as well as the donor. This implies that each watchtower was paid for by one elite actor, a significant outlay of wealth rhetorically and ideologically positioned as an atonement for their sins just like a religious donation.

107 On the crucial role of resistance in political economy, see Bernstein, Class Dynamics, 95-100.

108 Ibn Khaldūn, Muqaddimah, 281.

109 Babayan, Zakarid power.

110 Divan, ed. Orbeli, 12:5, 15:6, 17:6-7 and 23:8. 
None of the donors have aristocratic surnames, titles or honorifics, while some name their fathers, like Sargis son of Georg in 1209, ${ }^{111}$ some their towns of origin, like Mkhitar of Ganja in $1216,{ }^{112}$ and some giving no information at all, like a certain Simeon in $1217 .{ }^{113}$ Two are in the voices of women, Mamkhatun and Shanush, ${ }^{114}$ and three note how they constructed the towers from their halāl wealth, ${ }^{115}$ including Mamkhatun paying out of "my inherited (hor, lit. "my father's") and halal coin (dram) which I was given «. ${ }^{116}$

Once again, therefore, Ani's mural inscriptions represent the urban elite taking on a key role normally reserved to a ruling class, paying for military-urban infrastructure out of their own pocket. All mural inscriptions from the urban elite date to after 1209, when Ani was sacked by the sultan of Ardabil, and may represent these actors responding to Zakare's failure to defend the city. They certainly place the urban elite on a more or less equal footing to the Zakarian-Mkhargrdzeli, although in his 1201 donation to Horomos, Tigran describes himself as "loyal to my baron Zakaria «. ${ }^{117}$ This parity is especially clear in a unique piece from 1231, on a wall rather than a tower and seemingly naming those responsible for its renovation rather than taking the form of a single donor inscription. It reads "[Erected] in the year 670 (1231), may the Lord God protect Zaza and Baron Shāhānshāh, Gogorn, Vahram Patrik, Ohanes, Mkhitar, Mkhitarichn, Sargis «. ${ }^{118}$ The reigning Zakarian-Mkhargrdzeli appears in a list of actors without distinction or special mention, only indicated by his lordly title. It might be argued that the Zakarian-Mkhargrdzeli forced wealthy elite actors to »donate«, extorting rather than paying for renovations themselves. But were the rulers powerful enough, they surely would have imposed a tax instead and paid for the renovation in their own name - most mural inscriptions mention the reigning amirspasalar, but not all do, including Mamkhatun's of $1220,{ }^{119}$ and none grant the ruler honorifics like those found in an 1198 inscription at Horomos, dedicated to "the lordship, over this city and this whole country of Great Armenia, of the great generals of Christ, Za[kare] and Ivane: may the Holy Trinity protect them! ${ }^{120}$ Nor, for that matter, do any inscriptions mention the Georgian monarch - even Zakarian-Mkhargrdzeli inscriptions are modest in their self-representation, only distinguished from the urban elite by their titles, listed without hyperbole.

111 Divan, ed. Orbeli, 11:5.

112 Divan, ed. Orbeli, 2:1-2.

113 Divan, ed. Orbeli, 7:4.

114 Divan, ed. Orbeli, 5:3 and 8:4. For a study illustrating the potentials open to elite women in this period, see Eastmond, Tamta's World and Pogossian, Women, identity and power.

115 Divan, ed. Orbeli, 3:2 and 18:7.

116 Divan, ed. Orbeli, 5:3.

117 Horomos inscriptions, ed. Karapetyan and Mahé, 40:440-441.

118 Divan, ed. Orbeli, 10:5.

119 Divan, ed. Orbeli, 5:3.

120 Horomos inscriptions, ed. Karapetyan and Mahé, 31:430-431. 
Under the amirspasalar the city was ruled by a kind of lord mayor named the "amir" (amir/amira) assisted by a council of leading urban elite actors bearing titles like malik (lit. Arab. "king", here referring to a more general official), the aforementioned chancellor, the hečup/hājib, and a judge known by the Arabic title $q \bar{a} \bar{x}_{\bar{l}},{ }^{121}$ alongside the high clergy, including both an archbishop for the region and a bishop for the city - one prominent holder was Barsegh, abbot of Horomos 1229-1253, bishop of Ani, and son of Amir Erkat. ${ }^{122}$ Interestingly the urban administration is not mentioned in mural inscriptions, and none of the donors carry titles, which perhaps reflects an epigraphic culture that emphasised titular modesty, in turn reflecting the non-aristocratic urban elite's social and cultural hegemony borne of their dominance in the regime of accumulation. Offices are referenced in other inscriptions in Ani as well as at Horomos, however, and notably none of the holders come from the Zakarian-Mkhargrdzeli family. ${ }^{123}$ This fact, alongside the titles' implied high status, suggests a relatively corporate urban governance in Ani reflected in the mural inscriptions. Given the prominence of Arabic titles, this urban governance may have continued more or less directly from the twelfth century, only with Zakarian-Mkhargrdzeli barons appointing Armenian Christian amirs, hạjibs, maliks and qādīis - a phenomenon that speaks to the fundamentally Arabic-Islamic language of urban administration in the region and period, and Armenians' intrinsic situation in the Caliphal and post-Caliphal world, as Seta B. Dadoyan has extensively argued. ${ }^{124}$ Direct continuation from the twelfth century is especially likely since administrative titles appear from the beginning of the regime - for example, an 1198 donation to Horomos records the hečup Grigor, the same figure who in 1201 donated the village of Erdk "which I had bought" and described himself as father of "Amir Hasan «. ${ }^{125}$

The image, then, is of an elite hegemonic in the city's political regime as well as its regime of accumulation, together constituting an urban polity run by and for the benefit of merchantrentiers under Zakarian-Mkhargrdzeli protection. This would have allowed the urban elite to maintain low tax rates, keeping a competitive position as an entrepot in medium- and long-distance commerce, much as Ibn Khaldūn recommends. ${ }^{126}$ Taxation took place, certainly elsewhere in the Zakarian-Mkhargrdzeli regime and no doubt in Ani and its environs too,

121 The qadi of Ani is found participating in a legal assembly at Dvin under atabeg Ivane with the qadis of Tiflis and Dvin and the sheikh (shex) of Surmari, urban representatives adjudicating alongside court officials and clergy; see Orbelean, History, ed. Shahnasareants, 99-100.

122 Horomos inscriptions, ed. Karapetyan and Mahé, 43; Mutafian, Ani After Ani, 160; and Sinclair, Trade, Administration, and Cities, 180.

123 Divan, ed. Orbeli, 57:16-17; Horomos inscriptions, ed. Karapetyan and Mahé, 19:418-419, 21:421-422, 31:430-431, 44:444-445 and 45:446-447.

124 Dadoyan, Islamic World.

125 Horomos inscriptions, ed. Karapetyan and Mahé, 31:430-431 and 21:421-422.

126 Ibn Khaldūn, Muqaddimah, 231-232. 
but there is no surviving evidence for the forms this took. Indeed, the lack of inscriptions from Ani and its environs recording tax exemptions on donated property, seemingly always a prerogative of the ruler, whether royal or imperial, and evident in the Bagratuni, East Roman and Mongol eras, ${ }^{127}$ may be telling in itself, indicating a much lighter burden than preceding or subsequent periods, as well as in other regions contemporaneously. ${ }^{128}$

In these other regions the Zakarian-Mkhargrdzeli regime was constituted by lords, whose class position provides a useful contrast to Ani's elite. Most were military newcomers installed by the brothers following conquests in a system of grants probably close in principle to Seljuq iqtata ${ }^{129}$ These lords appear to have controlled property in much the same manner as Ani's urban elite, controlling villages as fiscal units rather than the land itself. Rights to shares appear much less common, but this fits the picture of freshly granted lands rather than a long-held system of partible inheritance. For example, in a 1223 donation by Bupak, prince of princes (išxan išxanac) under atabeg Ivane, to the monastery of Noravank in Siwnik, his property is described as halall hayrenik', and he notes the granting of the village of Aghberis with full tax exemptions, given to him by "my barons (paronayk') with a great charter « after he had conquered it from Muslims »by the strength of my arm and by the shedding of my own blood «. ${ }^{130}$

These actors were lords in the sense that they held juridical rights along with their control of significant property revenues, settled in fortified sites and required to provide military service, but they appear to dispose of fairly similar levels of wealth to Ani's mecatun, and generally far less than Tigran. The mecatun's involvement in medium- and long-distance commercial exchange enabled them to accumulate more properties and village rents, giving a competitive edge within the elite. Thus lords were disciplined into likewise accumulating from medium- and long-distance commercial exchange, constituting themselves as merchant-lords, notably by building caravanserais. ${ }^{131} \mathrm{~A}$ good example is the military newcomer Vache, who established the eponymous Vachutian family, and was the first holder of the title prince of princes under Zakare, given lands across the Ayrarat plain and purchasing the castle at Amberd from atabeg Ivane. ${ }^{132}$ Prince Vache constructed a caravanserai in the Kasakh Valley in 1213, two years prior to Amberd's purchase in 1215, building and renovating several churches at the same time. ${ }^{133}$ Only $500 \mathrm{~m}$ from the caravanserai is the village of Ambroyi,

127 For example, one of 1247 records a house gifted »free from duty«, Horomos inscriptions, ed. Karapetyan and Mahé, 420. There are other interpretations of this absence, for example that the Shaddadid emirs and Georgian monarchs were simply disinclined to grant exemptions, but given the absence of almost two centuries, a general shift in relationship between the urban elite and the rulers seems a better explanation.

128 See, for example, the tax exemption granted to Shirakavan in 1228: Pogossian, Women, identity and power, 242.

129 Bedrosian, Seljuk and Mongol periods, 253-254; Babayan, Zakarid power; La Porta Reconstructing Armenia, 259.

130 Orbelean, History, ed. Shahnasareants,101-102.

131 See the discussion in Franklin, Vorderstrasse and Babayan, Late medieval village, 124-128; eadem., Early Results, 304-316; eadem., A house for trade.

132 On this figure and his position as a merchant-lord, see Franklin, World, 79-93 and 98; and Babayan, Zakarid power.

133 As Kathryn Franklin notes, the Zakarian-Mkhargrdzeli elite consisted of almost brigand-like military newcomers converting the spoils of conflict into claims to political authority, alongside the mercantile mecatun, an »emergent nobility, appointed to power by the Zakaryans and their peers, consist[ing] of merchants who purchased noble titles and rimmovable feudal property with cash gleaned from developing trade along the mountain highways and from their widely dispersed shares in workshops, mills, and markets«. Franklin, A house for trade, 3. 
and ceramic finds at both sites indicate that they were connected through socio-economic relations, including commodity production of the ceramics' perishable contents, particularly foodstuffs to support the commercial foundation. ${ }^{134}$ Caravanserais could also own the rights to village rents in part or whole, ${ }^{135}$ a situation which may have pertained in this case. The image emerges of a military newcomer, established as a juridical lord and able to accumulate through village rents, who used his accumulated wealth to first build commercial infrastructure predicated on medium- and long-term exchange, and then purchase further accoutrements of lordship. ${ }^{136}$ Vache did not merely choose to invest in this manner; to a greater or lesser degree he was disciplined into doing so by the precociousness of mercantile elite actors in Ani and elsewhere.

Under the Zakarian-Mkhargrdzeli, therefore, although the atabeg and amirspasalar had decisive coercive force, granting lands to make lords and on occasion appointing the heads of large villages, Ani's urban elite was hegemonic in the city's regime of accumulation and political regime. This hegemonic position gave Ani's merchant-rentiers class power beyond the city's environs, disciplining military newcomers into reproducing themselves as merchant-lords. Ani's position in "transit trade« thereby constituted an internalised dynamic in the city's regime of accumulation as well as its political regime, becoming "external « again through the urban elite's patterns of reinvestment to both facilitate intercontinental exchange and dominate landholding, affecting the general configuration of the whole Zakarian-Mkhargrdzeli sub-polity. By keeping tax rates low, the urban elite maintained Ani's competitive position as an entrepot in medium- and long-distance nexuses, investing accumulated capital in production for short- and medium-distance commodity circuits like cotton alongside properties exploited through cash rents. This dynamic monetised subaltern relations, and made their productive labour dependent on commercial exchange to a greater or lesser degree. Overcoming subaltern counterpower with coercive force provided by the Zakarian-Mkhargrdzeli, Ani continued to urbanise on the basis of a merchant-rentier regime of accumulation - the mode through which valorised subaltern labour was realised. This agency in the built environment is seen in two undated early thirteenth century donations to Horomos, one in which a certain Grigor gave two houses with three shops above them "which I have built from my halal income «, ${ }^{137}$ and another where a certain Aryuts grants a shop "in the main street of Ani which I had bought and repaired; its lower side is close enough to Avetik's house. [I also gave] two small shops - one above the [main] shop and one in front of it: below there is a moneychanger. ${ }^{138}$

134 Franklin et al., Late medieval village, 126.

135 Trépanier, Foodways, 31.

136 As Franklin notes: "Rather than a determinate, developmental path followed from feudal tenure to urban capitalism, the expansion of trade in the medieval period involved the opening of opportunities as old structures were manipulated by new actors, who deployed their gains on local and emerging `world« scales«; see: Early results, 314 .

137 Horomos inscriptions, ed. Karapetyan and Mahé, 30:430.

138 Horomos inscriptions, ed. Karapetyan and Mahé, 50:453-454. 
Ani Under Mongol Rule, 1236-1350

In the margins of a manuscript copied at Horomos a scribe noted that in 1236 »the Tatar took Ani and the whole world «. ${ }^{139}$ Thus the city, its regime of accumulation, and the whole Zakarian-Mkhargrdzeli regime were integrated into the evolving empire of the Great Khans. ${ }^{140}$ As noted, Mongol pan-Eurasian hegemony constitutes the medieval Silk Road's political realisation, the state form apposite to the Commercial Revolution's apogee. In the last section we saw how interregional and intercontinental commerce constituted an essential vector within Ani's merchant-rentier regime of accumulation, disciplining subaltern labour alongside the urban elite, as well as - externalising once more - the lords beyond the city's environs. Likewise, this section demonstrates how apparently »external« Mongol taxation constituted an internal vector in Ani's political economy, conditioning the exploitation of subaltern labour for capital accumulation and rents, and producing pressures both on and within these processes to which both subaltern and elite classes could respond in various ways. The manner of their response dictated this vector's »re-«externalisation. The question is the balance of forces at play: the extent to which interregional and intercontinental commerce was conducive to regional and local merchant-rentier accumulation, on the one hand, and, on the other, the extent to which the Mongol state system assured necessary levels of coercion, while not taxing to the point of endangering accumulation through capital and rents, so that subaltern counterpower could be overcome and urbanisation thereby continue.

Much secondary literature claims or implies that Ani's 1236 Mongol conquest was a disaster, and the violence of the initial moment is indicated by chronicles, a 1236 manuscript colophon, and three later inscriptions at Horomos Monastery mentioning bloody destruction and times of troubles "caused by the Tatars ${ }^{141}{ }^{141}$ But Mongol rule did not drastically affect Ani's merchant-rentier regime of accumulation, especially at first. Rather, Mongol hegemony over Eurasia provided a significant stimulus to mercantile activity, integrating the city more directly with commercial nexuses across Eurasia. What did change was the political regime, now subordinated to and integrated within the Mongol state system. ${ }^{142}$ Ani's elite continued to have an official role in urban governance, with civic titles attested in inscriptions, but this governance was now firmly subject to Mongol rule, much like the Zakarian-Mkhargrdzeli themselves. Ani became an administrative centre of the Mongol and subsequently Ilkhanate province of "Georgia«, with the Great Khan confirming the Zakarian-Mkhargrdzeli governor and appointing an imperial commissioner alongside him.

139 This is MS. Yerevan 2865, held in the Matenadaran.

140 For the Mongol period in Caucasia, and relationship to various Armenians, see Dashdondog, Mongols. Kirakos curiously attributes the key agency in Ani's 1236 Mongol sack to the urban subaltern classes, who, he claims, killed the Mongol ambassadors while the civic elite waited for permission to surrender from the reigning ZakarianMkhargrdzeli, see Kirakos, History, 220-221.

141 Horomos inscriptions, ed. Karapetyan and Mahé, 47:450-451, 56:461-462 and 57:463.

142 For an in-depth overview of Mongol administration in Caucasia, see Dashdondog, Mongols, 99-120. On Mongol taxation more broadly, see Schurmann, Mongolian Tributary Practices; Smith, Mongol and Nomadic Taxation; Ostrowski, »Tamma« and the Dual-Administrative Structure, 262-277. 
As noted, little is known about Ani's taxation in the twelfth and early thirteenth centuries, but it appears to have been especially light. With the imposition of Mongol rule this was no longer the case, and the political regime oversaw steadily increasing taxation, heavy but initially relatively ad-hoc, under Mongol governors, prompting a lordly rebellion in 1248-49. ${ }^{143}$ Taxation underwent a step change from c.1254-55, when Armenian histories as well as the Georgian royal chronicle, the $K^{\prime}$ art 'lis C'xovreba, describe a huge census, part of a process of imperial stabilisation across Eurasia in the 1250s, which also witnessed the transition to regional sub-khanates or ulus from 1256, in Iran and Caucasia the Ilkhanate under Hulegu. The census formed a vast process of registering all the various property arrangements indicated in the previous section, generating new pressures from novel demands at the moments of appropriation and distribution. As the Georgian chronicle comments:

Then Arghun came to Khan Ulo, who welcomed him with honors and sent him to Georgia, to King David, and to Greece (central Anatolia), and all the other lands subject to him, and he took a census and regulated the problems of government. When he came to Georgia, the whole population of David's kingdom was in great distress. And lists of everything were made, starting with people and ending with beasts, from fields to vineyards, and from orchards to vegetable gardens. And from every nine well-off peasants they took one for military service...And the size of the tribute was established; from one village for the commander of a thousand horsemen, they took one lamb and one drahk'an (gold coin), and for the commander of a bevri - one sheep and two drahk'ans, and the fee for a horse was three tetris (silver coin) daily. ${ }^{144}$

The listing of property types seen in inscriptions, including fields, vineyards, orchards and gardens, as well as the people and livestock engaged in productive activity, is particularly notable. Their registration and taxation would change the manner of their use and exploitation, much as later in the narrative David of Georgia is described as "constrained by the census of Arghun ", which obliged him to put aside three silver tetri for every one hundred made in Tbilisi. Payment was assured by the presence of an imperial commissioner, in Tbilisi a certain Khoja-Aziz who imposed a »kharaj (lit. land tax, here a generalised term), which they call t'amgha, on the purchase of a sheep or lambs for the King's kitchen «. ${ }^{145}$ Importantly the tamgha is a commercial tax, and in the narrative the king is "pressured by these circumstances", a pressure that should be imagined more or less across the population, with some choosing to resist - as David himself chose, apparently because of the "arrogant " Khoja-Aziz "who was set above me by Arghun". Arghun even appears a second time after the subsequent revolt to "make an inventory of the lands and find out to what extent they were ravaged or rehabilitated«.

143 On Mongol taxation in Caucasia see: Dashdondog, Mongols, 111-120.

$144 K^{\prime}$ art'lis $C^{\prime} x o v r e b a$, ed. Jones et al., 350.

$145 K^{\prime}$ art'lis C'xovreba, ed. Jones et al., 352. 
So the census enabled Mongol rulers to impose a wide range of novel and newly regularised taxes, all collected in silver coin. Mongol impositions necessarily engendered resistance, in particular another lordly rebellion in 1260 following the imposition of the qubčur, a poll tax varying in scale from one dinar to 500 depending on personal wealth. ${ }^{146}$ Subaltern counterpower is difficult to locate in narratives focused on elite actors concerned with their own class power, but it can be critically imagined from the recording of the census in Kirakos' history and Grigor of Akner's History of the Nation of the Archers. ${ }^{147}$ Kirakos claims that »They began recording everyone from age eleven up, excepting the women, and they demanded the most severe taxes, more than a man could bear, and so people became impoverished." Likewise, Grigor describes how Arghun took a headcount across the whole country for taxation, compiled into a "davt'ar (Arab./Pers. daftar)« or register, and from this demanded tax: "in one village they recorded thirty to fifty men, each [ranging] from fifteen years of age up to sixty, and from each head they counted, they took sixty spitaks (silver coins)." Non-payment was met with extreme violence, as ever, and Kirakos notes the "unbelievable beatings, torments and tortures", with those who fled and were caught suffering a special form of execution gruesomely detailed by Grigor. Finally, any unable to meet the demands had their children taken in payment of the debt. Such latent and realised violence must be imagined playing out in countless moments of registration, calculation and tax demands in Ani and its environs, as the registrars and tax collectors encountered each particular household and property arrangement, adding further demands for coin on top of pre-existing rents, further compelling subaltern actors to take on wage labour, enter debt relations, and commodify produce. Sources consistently emphasise both the comprehensiveness of the registration and the violence, both at the initial registration and subsequent moments of appropriation, forming the engine for an increased counterpolitical dynamic, empirically invisible as ever, but the dark matter structuring elite actions in this period, both in revolt against the new rulers and in collaboration with them.

This is important, since Kirakos claims that "the princes, lords of the districts, became their [the Mongols'] collaborators in harassing and demanding taxes for their own profit «. ${ }^{148}$ The historian indicates the lords of the Georgian monarchy's integration into the Mongol's state system through tax-based accumulation, thereby asserting their domination over subaltern classes. Certainly this collaboration was not straightforward: lords were subject to taxation as much as they profited from it, and the process of registration held dangers for them too. For example, the abbot of Noravank Monastery and historian Stepannos Orbelean describes how the prince of Siwnik, Smbat Orbelean, had many lands taken from him and heavy impositions on what remained. ${ }^{149}$ Yet this was not due to the Great Khan's representatives, but rather other Georgian lords, who apparently influenced Arghun in order to disinherit Smbat for their own benefit - a perfect illustration of "external « Mongol taxation's transformation into an internal vector within Caucasian regimes of accumulation. Unlike subaltern actors, however, Smbat's class power and political status meant he was able to visit

146 Dashdondog, Mongols, 92.

147 All subsequent quotations from these historians can be found in: Kirakos, History, ed. Melik-Ohanjanyan, 360362; Grigor of Akner, History of the Nation of the Archers, ed. Blake and Frye, 321-324.

148 Kirakos, History, ed. Melik-Ohanjanyan, 362.

149 Orbelean, History, ed. Shahnasareants,158-16o. 
the Great Khan himself and leverage his position for restoration and privileges - another instance of "re-«externalisation. ${ }^{150}$ Nevertheless, such instances notwithstanding, Mongol rule constituted a sudden assertion of taxation's hegemony over Caucasian regimes of accumulation, evoked in Kirakos' description of the broad range of newly taxed persons: artisans, "whether in the cities or the villages", fishermen in both seas and lakes, miners, blacksmiths and fresco painters. Likewise productive resources such as salt mines were taken over by the new rulers. Overall, as Kirakos comments, "Is it necessary to explain in detail the level of profit which they extracted from people?"

This violent assertion of taxation's hegemony specifically affected the capital accumulation of merchants, from whom the Great Khans "profited greatly" and "heaped up vast quantities of gold, silver and precious stones«. Interestingly, however, Kirakos mentions one merchant, a certain Umek from Karin-Erzerum, around $250 \mathrm{~km}$ southwest of Ani, who gave generous gifts to Arghun "and those with him ", and was greatly admired by the Khan and his representatives - admiration expressed »in writing " which also confirmed private property and granted tax exemptions. ${ }^{151}$ This suggests that some merchants were able to leverage their class power even in the new conditions of a powerful tax-based hegemony, with the state system responsive to the needs of capital accumulation. Yet this responsiveness was conditioned not by the necessities of mercantile and rentier accumulation in itself, as under the ZakarianMkhargrdzeli, but rather by the desire to extract tax. So, as Kirakos comments, »everything became expensive and the lands became filled with lamentations and complaints", neatly bearing out Ibn Khaldun's analysis of commercial taxation's impact on prices and so general expenditure relative to income. ${ }^{152}$ Nevertheless the Great Khan's representatives remained ever-present, demanding "the same amount every year by list and in writing «. ${ }^{153}$

So the mid- to late thirteenth century saw heightening contradictions between tax-based and merchant-rentier regimes of accumulation. Mongol taxation further pressed subaltern classes already commercially and financially exploited, introducing yet more cash demands on top of pre-existing rents as well as their various exploitation through wage labour, unfree tenancy and debt, forcing them to change productive activity accordingly. For example, an inscription of 1274 records how Ukan Karimatin, Papkan Varkhatin and Pakpan's wife Dapta Khatun, bought half of Horomos Monastery "from our halal wealth" - a remarkable act in itself - donating in return tax-exempt properties and seemingly one peasant family. ${ }^{154} \mathrm{Al}-$ though fragmentary, inconclusive, and the sole such instance, ${ }^{155}$ this may indicate that the pressure on subaltern actors encouraged some to take on not just unfree tenancies, but a form of legal serfdom tied to village units. ${ }^{156}$ The counterpower necessarily emergent from increased fiscal exploitation would endanger sub-hegemonic elite classes and, coupled with increased demands on elite actors themselves, encourage their revolt.

150 He even becomes a personal vassal of the Great Khan, an inju; see Orbelean, History, 154.

151 Dashdondog, Mongols, 117.

152 Ibn Khaldūn, Muqaddimah, 276-278.

153 Kirakos, History, ed. Melik-Ohanjanyan, 362.

154 Horomos inscriptions, ed. Karapetyan and Mahé, 71:476.

155 This is the sole such instance in Ani, but a 1244 inscription at Astvatsnkal in the Kasakh Valley in the name of the local lord, Kurd Vachutyan, dedicates a peasant (šinakan) alongside more standard property types. See Kate Franlin, Everyday Cosmopolitanisms.

156 This case is mirrored by the donation of a šinakan to a church by the merchant-lord Kurd Vachutyan to a church in 1244; see Franklin, Everyday Cosmopolitanisms, 77. 
These heightening contradictions can be located in the configuration of the Great Khans' state system, what Anievas and Nisancioglu term a nomadic mode of production and David Sneath the "headless state ${ }^{157}$ In such configurations expanded accumulation cannot be generated by the development of productive forces or increased cultivation of land, necessitating the integration of more and more units from which to extract tax, including facilitating commercial exchange so as to tax it more effectively. Accumulated tax is then distributed through a relatively horizontal hegemonic nomadic elite, engendering a contradiction between tendencies to sedentarise and stratify into a more normative tax-based regime, like the Yüan dynasty in China, or to disaggregate and reaggregate variously over time and space, as across post-Mongol Iran and Central Asia. ${ }^{158}$ Kirakos provides a notable vignette of a nomadic regime when he describes Mongol lords dividing up by lot »the lands of Armenia, Georgia and [Caucasian] Albania", "each chief according to his importance receiving cities, districts, lands and fortresses «. ${ }^{159}$

A nomadic configuration, hegemonic across Eurasia, allowed Ani's now politically subhegemonic elite to continue to accumulate capital and collect rents across the remainder of the thirteenth century, but at the expense of increased taxation. The massive expansion of accumulation in general, a result of the Great Khans' deeper integration of the Commercial Revolution's interregional and intercontinental nexuses, overcame the heightening contradiction between tax-based and mercantile-rentier accumulation in the city and its environs. This was particularly the case in the Ilkhanate, where the tamgha directly supported the Ilkhan's court and military campaigns, indicating in turn the large revenues commercial taxation could provide. ${ }^{160}$ The Franciscan friar William of Rubruck visited the city and region in late January and early February of 1255, and notes the many prosperous villages and Ani's impressive buildings, ${ }^{161}$ as would two Nestorian monks two decades later. ${ }^{162}$ These two testimonies appear during the transition to Ilkhanate regional rule following the census in 1256, and the Ilkhanate's subsequent establishment in Tabriz from 1265, indicating a relatively smooth transition - also reflected in Ambroyi's stable social life throughout the thirteenth century ${ }^{163}$ As the village's excavators' note, "the Ilkhanid period in Armenia not only stimulated the production and maintenance of infrastructure like road inns, but also tied villages as well as cities into regional and even larger-scale webs of shared material culture and practice. ${ }^{164}$

157 Anievas and Nisancioglu, How the West, 67-70; Sneath, Headless State. The Ilkhanate's trajectory can also be compared with Ibn Khaldūn's analysis of the general stages of state systems emerging from nomadic groups; see Muqqadimah, 141-142.

158 Cf. Ylldız , Post-Mongol pastoral polities.

159 Kirakos, History, ed. Melik-Ohanjanyan, 236-237.

160 Dashdondog, Mongols, 114.

161 William of Rubruck, Mission, 269.

162 Mutafian, Ani After Ani, 161-162.

163 Franklin et al., Late Medieval Village, 113.

164 Franklin et al., Late Medieval Village, 124. See also the situation at Arpa in Vayots Dzor to Ani's southeast, Babajanyan and Franklin, Everyday Life, 155-183. 
In Tabriz the Ilkhanate began to mint silver coins, which quickly became the region's new standard, replacing the previous gold - a transition between the two "measures of value for all capital accumulations « which Ibn Khaldūn claims God established. ${ }^{165}$ This represents a hegemonic shift from Mediterranean to Asian mediums of accumulation driven by Mongol taxation in silver coin, which represents in turn taxation's hegemony over merchant capital - eloquently demonstrated in the so-called empire of Trebizond minting East Roman motifs on the Ilkhanate's silver standard for a city with a strong Genoese presence. Positioned on nexuses connecting Tabriz to Anatolia, northern Caucasian regions and the Black Sea, and now subject to a wide range of taxes in silver coin, the standard was adopted in Ani too, with inscriptions revealing an almost instantaneous shift. For example, in an inscription of 1276, a certain Sahmadin describes how in 1261, during "the rule over the world of Hülegü Khan", he bought a royal palace "with my halal hayrenik' for my own use and that of my children « from Artashir, son of Shāhānshāh, in the town of Mren just to the southwest of Ani on the Shirak plain, renovating the building and spending a total of 40,000 gold coins. ${ }^{166}$ This inscription is revealing for power relations between the urban elite and the ZakarianMkhargrdzeli, with many lords selling off lands after the qubčur's introduction ${ }^{167}$ and finding cash-rich merchant-rentiers able to pay in coin, in 1261 still gold. Likewise, in an inscription of 1283 at Goshavank, a certain Char, son of Umek - likely the same actor mentioned by Kirakos, especially considering that the historian was writing at the monastery in these same years - mentions how his father bought the village of Getik for 40,000 gold coins in the early thirteenth century under the Zakarian-Mkhargrdzeli, while Char himself bought Hovk for four thousand gold coins »during hard times when land was cheap and gold dear «, again the aftermath of the census. ${ }^{168}$ In a 1269 donation to Horomos, however, coming four years after the Ilkhanate's establishment in Tabriz, a female elite actor named Taik-Taguhi gave "the grindstone of Abel by [Ani's] Dvin gate", which her son Harzpek had redeemed from debt mortgage to a certain Garegoyn for 700 silver coins, and repaired for another 800. ${ }^{169}$ Between 1261 and 1269, Ani appears to have moved from a gold to a silver standard without appreciable change in the merchant-rentier regime.

In fact, Char's donation indicates that Mongol taxation actually reinforced the generalised dominance of Ani's urban elite, resulting in an apparently significant concentration of capital. The sudden increase in cash demands elevated coin's value relative to property, so that owners were forced to sell off and Ani's cash-rich elite was well-placed to buy up - in this case an entire village's income, previously 40,000 gold coins, sold off for a tenth that sum. As Ibn Khaldūn notes, in moments where one state system replaces another, the turmoil lowers the value of real estate and it can be bought up for low prices. ${ }^{170}$ The same dynamic seems

165 This was part of a broader regional shift to silver evident from c.1240; see Sinclair, Eastern Trade, 48. For an indicator of Tabriz's new centrality, see Johannes Preiser-Kapeller, Civitas Thauris. The Significance of Tabriz. Ibn Khaldūn, Muqaddimah, 298.

166 Manandian, Trade and Cities, 188.

167 There was also a rebellion in 1260, and in 1261 some lords were executed for non-payment; see Dashdondog, Mongols, 115 .

168 Manandian, Trade and Cities, 186.

169 Horomos inscriptions, ed. Karapetyan and Mahé, 62:468.

170 Ibn Khaldūn, Muqaddimah, 280. 
to lie behind Artashir's sale of the palace at Mren in 1261, as well as the purchase of half of Horomos in 1274 , with the monastery receiving specifically tax-free properties in return. In principle the monastery should have been free from all taxation, as all religious institutions under Mongol rule were, but Horomos' fiscal difficulties are indicated already in 1251, when a certain Yovanes Chkhik redeemed and renovated the monastery's mill, which had been debt mortgaged and ruined "after the ravages of the Tartars", paying 40 gold coins. ${ }^{171}$ Thus Mongol taxation's internalisation as a vector within the city's regime of accumulation had the effect of making coin more valuable, providing opportunities for the urban elite to further dominate property arrangements. Relatively humble-seeming actors continue to control village rents up to the thirteenth century's final decades, for example the physician Abd al-Hasan, who gave four-sixths of the mill in Saghuhndeler »in the valley of Aprnuts" to Horomos in $1273 .{ }^{172}$ This indicates that Ani's urban elite continued to act as a disciplining pressure on extra-urban lords, notably reflected in the later thirteenth-century appearance of formulae in donor inscriptions guarding against the encroachments of »either our own people or foreigners (i.e. Muslims), either lords or merchants (dzernawork) «. ${ }^{173}$ Of course, this formula suggests that competition was not between lords and merchants as such, but between cash- and land-rich elite actors, with Caucasian merchant-lords continuing to build caravanserais and so obtain a competitive edge up to the end of the long thirteenth century. ${ }^{174}$

Yet, although Ani's urban elite remained hegemonic in the city's regime of accumulation, there were heightening contradictions between tax and merchant capital which could only be overcome by the continued expansion of accumulation in general, a process which in turn compounded contradictions further. Although it cannot be detailed here, the Ilkhanate increasingly took the form of a more normative tax-based configuration, but never completed the transition, remaining mired in contradictions with tendencies towards a nomadic regime, and entering a liquidity crisis by the 1290s. Most striking is Ilkhan Geikhatu's ill-fated attempt to switch to paper money c.1291-1295, modelled directly on the Yüan dynasty's - itself modelled on the Song's - and including Chinese characters but with the Muslim confession of faith, which Orbelean claims was intended to "eliminate silver money", an "order issued with severity in all the cities «. ${ }^{175}$ Merchants refused to recognise the currency, and riots broke out in the market - the Persian historian Rashìd al-Dīn even names the new money "the ruin of Basra« ${ }^{176}$ The remarkably asynchronous nature of this historical moment aside, it clearly

171 Horomos inscriptions, ed. Karapetyan and Mahé, 57:463.

172 Horomos inscriptions, ed. Karapetyan and Mahé, 35:434-435.

173 Orbelean, History, ed. Shahnasareants,101-102 and 111-112.

174 For example the Orbelean caravanserai founded in 1332; see Babajanyan, Archaeological Excavations, $146-158$. Notably this is built in the reign of Abu Sa'ìd, the last recorded Ilkhan at Ani, and indicates a shift of investment to those nexuses connecting Tabriz to Sevan, Caspian and Tblisi, circumventing Ani and the Shirak plain.

175 Orbelean, History, ed. Shahnasareants,215.

176 Ashtor, Social and Economic History, 257. 
indicates the difficulties the Ilkhans faced in assuring the necessary coin for taxation. The response was, predictably, to deepen taxation further, especially in those sites which had provided significant tax revenue up to this point. ${ }^{177}$ In a donor inscription of 1301 to the church of the Holy Apostles in Ani, the Zakarian-Mkhargrdzeli governor Aghupugha claims that "the city had become impoverished and was deeply wounded, because it was overwhelmed by such taxes as had never existed since the beginning ", absolving the foundation of three of these for the sake of »the life of the land «. ${ }^{178}$

Simultaneously and internally connected to increases in taxation, nexuses of commercial exchange began to shift away from Ani in the later thirteenth century. As Manandian and Sinclair have demonstrated, these moved both northwards, north of the Caspian and across the Pontic steppe to the Crimea, as well as southwards, from Tabriz, north of Lake Van, to Upper Mesopotamia, northern Syria and Cilicia. ${ }^{179}$ The movement was not uniform or total, some medium-distance nexuses continued to pass through the Shirak plain into the later fourteenth and fifteenth centuries, and the extent of long-distance movement $c .1300$ is open to debate. Yet, as a result of tax increases blunting the city's competitive advantage as an entrepot, Ani was no longer on the primary route carrying luxury commodities from India and China to Anatolia, the Black Sea and the Mediterranean beyond. Importantly, the first decades of the fourteenth century witness an "economic quickening " in the cities to the south of Ani, along the north shore of Lake Van. ${ }^{180}$ The province of "Great Armenia « began to provide the Ilkhanate around four times the tax revenue of "Georgia « to the north, a dramatic reversal from the mid-thirteenth century when "Georgia" provided three times the revenue of "Great Armenia ${ }^{181}$ The loss of capital accumulated from long-distance luxury circuits would make auxiliary short- and medium-term commodity circuits less profitable, necessarily resulting in their contraction, with obvious consequences for subaltern actors with tax receipts to pay. In this manner the ability of Ani's urban elite to accumulate capital steadily decreased, revenue which could only be made up for by raising rents, again impacting subaltern classes. But the contraction of commodity production and exchange on every level meant fewer mechanisms by which subaltern actors could obtain coin to pay these rents, while at the same time Ani's elite had less and less cash to invest in further incomes. Finally, in addition to this specific regional transformation, in the first half of the fourteenth century Latin Christendom entered its profound late medieval crisis, providing less intercontinental demand for long-distance commodities overall, and so contracting the total capital available across the Afro-Eurasian world system, thereby constituting an essential vector for its general crisis in turn.

177 Cf. Hakobyan, Ani, 270-273.

178 Divan, ed. Orbeli, 84:27-28.

179 Manandian, Trade and Cities, 189-201; Sinclair, Trade, Administration, and Cities, 187-191; and idem, Eastern Trade, 75.

180 Manandian, Trade and Cities, 200.

181 These toponyms are in quotation marks as they refer to the Mongol and Ilkhanate provinces, rather than transhistorical »countries« of this name. 
Hence long-distance exchange and Mongol taxation are not alternative explanations for deurbanisation, but internally related elements of a total configuration, which, in turn, interacted with other elements to cause deurbanisation. Ani continued to have a reputation for large tax revenues, with the Ilkhans taking the step of naming the city a khas inju, a personal estate taxed directly. This is attested in an inscription above Ani's main "Lion Gate«, dated sometime soon after $c .1319 / 20$, when a Zakarian-Mkhargrdzeli governor is last attested. ${ }^{182}$ The piece opens by describing how »the long-lifed King of Kings, God-given $p$ 'at'šah (Pers. pädishäh) and God-knowing Prince of Princes of the land, and of the kingdom of this land of the Georgians, made the mother-city of Ani [their] khasinjou«. The change took place »in the lordship over this city of the God-loving patronk' Grigor agha and Yovhannes «, ${ }^{183}$ who are the last known representatives of Ani's urban governance, now firmly subordinate to a hyperbolically dominant ruler. Grigor and Yovhannes are credited with renovating the city walls, presumably the main gate in particular, and charged with administering all tax collection. The remainder of the inscription describes various taxes which they removed, including the taghma (datma). The Ilkhans had clearly seen Ani as a significant source of tax, especially drawn from commerce, which could help them overcome political-economic crisis. By this point, however, Ani's regime of accumulation had dislocated to the point that this was no longer the case. Grigor and Yovhannes were wealthy enough to pay for renovations, but the urban elite's generalised dominance in property arrangements, so evident across the thirteenth century, is no longer clear - at Horomos no donations by the urban elite survive after the end of the thirteenth century, with the possible single exception of an undated grant of two cows and two oxen. ${ }^{184}$ Likewise, their agency in the built environment slowly fades, with no new public buildings attested after 1348 , although there are numerous repairs to existing churches - yet, as Ibn Khaldūn notes, repairs may continue long after the end of the urbanisation which constructed the structures in the first place. ${ }^{185}$ The inscription above the Lion Gate even indicates recent disruption in property relations, its closing statement noting that the patronk ' had "restored the previous [property] boundaries".

So capital accumulation on the scale required by Ani's regime of accumulation was simply no longer possible, and deurbanisation set in. This is seen in a Persian inscription of c.1330, erected by the last powerful Ilkhan, Abū Sa'īd, which abolishes all taxes bar two, customs duty and the taghma, stating:

...let nothing [else] be demanded as tax....as was done before at Ani and other cities in the province of Georgia, where under the pretext [of taxes], unlawful adscriptions and charges were collected and force used. [The city] started to become deserted, men from among the common people scattered, the elders of the city and of the province because of the [taxes]...abandoned their possessions real and movable and their families, and went away. ${ }^{186}$

182 Divan, ed. Orbeli, $1: 1$.

183 The use of the title agha is notable, a term with a long life in the region up to this day, in Turkish and Kurdish referring to powerful landowners who control villages, potentially indicating that Grigor primarily saw himself as such. See Van Bruinessen, Agha, Sheikh and the State, 80-81.

184 Horomos inscriptions, ed. Karapetyan and Mahé, 76:480.

185 Sinclair, Trade, Administration, and Cities, 191-192; and idem, Eastern Trade, 75. Ibn Khaldūn, Muqaddimah, $272-273$. 186 Manandian, Trade and Cities, 199. 
This inscription clearly indicates the relationship between increased taxation and deurbanisation as an external-cum-internal factor: the level of tax demands made property exploitation unprofitable, encouraging property owners to sell and leave. Likewise, the piece indicates the role of subaltern classes in this process, who exercised the most basic form of counterpower, refusal, and left. This has been interpreted as a result of the urban elite's decline, but the opposite is more likely: elite accumulation from both capital and rents depended on subaltern exploitation, and with a depletion of the workforce wages would rise, increasing costs and compounding the effect of increased taxation and falling commerce. Unlike the period of imposition of Mongol taxation, ruling elite classes, including both the regional Caucasian elite and the Ilkhan's representatives, could no longer exercise extreme violence to keep subaltern classes in place. Instead the urban elite left too, as seen in the story of a group of merchants who left for Astrakhan north of the Caspian in 1331, a key site on the northern commercial nexus connecting central Asia to the Crimea. ${ }^{187} \mathrm{Abu}$ Sa ${ }^{a} \mathrm{i} d$ sought to alleviate the tax burden to favour commerce, and only extract tax from this form of accumulation, but the merchant-rentier regime had already reached terminal dislocation.

Manandian and Sinclair both emphasise Ani's existence into the fifteenth century: coins continue to be minted at the site by ruling Turkmen groups who used it as an administrative centre, and Timur Leng sacked the city in 1400 , before turning south to Damascus where he would meet Ibn Khaldūn. ${ }^{188}$ Likewise, it must have taken some time for property arrangements to totally transform, as indicated by the last donor inscription at Horomos, dated to $1336 .{ }^{189}$ This is in the name of a Zakarian-Mkhargrdzeli, Varham (sic, more commonly "Vahram«), atabeg and patron of the barons, who apparently still had relatively extensive holdings even after Ani's dispossession, granting three villages "with their fields, soil and water, and their four limits «, abutting "the great merchant town of Mastara» to the east. Nevertheless, notwithstanding a nuanced image up to 1350, and an afterlife as an administrative centre into the fifteenth century, Ani's role is more by contingent default than its structural position, with only a micro-regional commercial function. ${ }^{190}$ By 1350 at the latest, Ani's merchant-rentiers, merchant-lords and the Zakarian-Mkhargrdzeli rapidly begin to fade into obscurity, their social positions bifurcating into a choice between reproduction as landlords on the one hand, as Varham and potentially also Grigor 'agha', and merchants on the other, like those who left for Astrakahan. The composite regime of accumulation that had produced Ani's urbanisation, combining capital accumulation from interregional and intercontinental commerce with village rentierism, binding together elite and subaltern classes in struggle, had dissolved, and both exploiters and exploited left.

187 Sinclair, Trade, Administration, and Cities, 181.

188 Manandian, Trade and Cities, 199 and Sinclair, Trade, Administration, and Cities, 183-184. Sinclair dates the definitive end of Ani's viability to the Ak Koyunlu campaigns against Georgia in the later fifteenth century; see Sinclair, Eastern Trade, 75. See also Mutafian, Ani After Ani, 163-165.

189 Horomos inscriptions, ed. Karapetyan and Mahé, 16:415-416. There are other inscriptions in the city of Ani, and Sinclair, following Hakobyan, uses these to argue for no deurbanisation by 1350 . Certainly there is a demand for nuance, but Horomos has been this study's measure and the total absence of inscriptions remains telling; see Sinclair, Trade, Administration, and Cities, 182; Hakobyan, Ani, 278.

190 This is its connection to Karin-Erzurum; see Sinclair, Trade, Administration, and Cities, 191-192. 


\section{Conclusion}

Ani's story bears out, deepens and concretises much of Ibn Khaldūn's general model, especially demonstrating that declining population is not disastrous in itself, but for the loss of subaltern labour which forms the basis for all wealth. As he writes:

We have stated before that a city with a large civilization is characterized by high prices in commerce and high prices for necessities. [The prices] are then raised still higher through customs duties; for sedentary culture reaches perfection at the time when the state system has reached its greatest flourishing, and that is the time when the state system levies customs duties because then it has large expenditures...The customs duties raise the sales [prices], because small traders and merchants include all their expenses, even their personal requirements, in the price of their stock and merchandise. Thus, customs duties enter into the sales price. The expenditures of sedentary people, therefore, grow...The people cannot escape this [development] because they are dominated by and subservient to their customs... One person after another becomes reduced in circumstances and indigent. Poverty takes hold of them. Few persons bid for the available goods. Commerce decreases, and the situation of the town deteriorates. ${ }^{191}$

In Ani we find a commercial centre whose urbanisation was driven by capital accumulation from the start, personified in a precocious and increasingly self-conscious urban elite. At the outset of the long thirteenth century this elite was already hegemonic in Ani's regime of accumulation. This depended on interregional and intercontinental commercial exchange but encompassed a wider range of regionally and locally integrated production, circulation and distribution, including auxiliary short- and medium-distance commodity circuits, as well as control of village rents which could be bought, sold, and divided into shares for inheritance and pious donations. The merchant-rentier regime disciplined subaltern labour, dominated and exploited through wage labour, debt and unfree tenancy, as well as diverse processes of commodity production - although it is impossible to identify the central bulk commodities which supported short-, medium- and long-distance commerce, cotton and processed textiles are certainly among them. ${ }^{192}$ Ani's "great-housed « elite actors leveraged their hegemony over accumulation to realise class power in the city's political regime too, constituting an urban polity within the Zakarian-Mkhargrdzeli regime and under the Georgian monarchy's regional hegemony, where Armenian Christian merchant-rentiers took office as amir, malik, $q \bar{a} \bar{d} \bar{l}, h \bar{a} j i b$, and various other titles.

.With Mongol rule and the imposition of heavy taxation this urban polity and its regime of accumulation became firmly sub-hegemonic to the emerging state system of the Great Khans, but the expansion of accumulation in general across the Afro-Eurasian world system overcame these new limits. Indeed, taxation's imposition provided new opportunities to further dominate landholding in the city, its environs and beyond, contributing to a consolidation of capital among the merchant-rentier elite. By 1300, however, this was no longer the case, with taxation increasing as a result of the Ilkhanate's liquidity crisis, intersecting with

191 Ibn Khaldūn, Muqaddimah, 286.

192 As Banaji notes, "The stronger the competition between commercial capitals, the greater is the compulsion on individual capitals to seek some measure of control over production«, Theory, 271. 
and contributing to the shift in commercial nexuses to the north and the south. Ani's urban elite no longer accumulated enough capital from interregional and intercontinental commerce to meet tax demands and sustain their local regime of accumulation, which began to dislocate in the general crisis of the Commercial Revolution. Lacking the class power borne of a robust hegemony over the local regime of accumulation, Ani's merchant-rentiers could no longer overcome subaltern counterpower, and exploited classes exercised their agency to simply leave, with the mecatun beginning to do likewise. Ani survived in a much reduced form to the end of the fourteenth century and for some time thereafter, but the predicates for its previous urbanisation had been removed along with the rest of the Shirak plain's urban constellation, by the early sixteenth century leaving Kars on Shirak's western edge and Yerevan just beyond Shirak's limit on the Ararat plain to the south east.

This story speaks to debates in historiography and political economy beyond Ani and immediately related scholarship. The interrelation of commerce and tax in Ani's trajectory reveals the mystification implicit in positive characterisations of the Pax Mongolica's relationship to "trade«, as well as negative visions of the Mongols' role in deurbanising and transforming landscapes. Mongol hegemony over Eurasia did »stimulate trade«, but for the very specific end of taxing commerce more effectively. The "peace" required for this effective taxation was constituted by extreme violence, latent or realised in every moment of its constitution, tranquillity the mere surface appearance of Mongol hegemony's operative integration of diverse regional elite actors and classes. On the other hand, arguments to the effect that Mongol rule de-agrarianised lands for nomadic pasture, resulting in the loss of urban centres - implicitly resting on a racist image of "non-state « barbarians versus civilisation do not hold for Ani and its environs. Far from their nomadism, it is the Great Khans' mastery of that sine qua non of state civilisation, ${ }^{193}$ tax, which brings about Ani's deurbanisation.

More broadly, Ani's story demonstrates how interregional and intercontinental commerce engender far more textured local and regional regimes of accumulation than common-sense characterisations imply: "transit trade" is far from transitory, it involves a profound disciplining and integration of subaltern labour in each particular short-distance configuration of production, appropriation and distribution which together constitute medium- and long-distance nexuses. Thus external factors become internal and vice versa, so that analysis of the particular sites of accumulation generated by interregional and intercontinental commerce requires a thorough investigation of the local political economy. The same goes for apparently »external« taxation, in this case Mongol but indicating more general dynamics. Although initially a demand "from outside", taxation is internalised within local regimes of accumulation according to their pre-existing dynamics, and its effects likewise vary accordingly. Ani appears a victim of its previous commercial success, taxed to the point that it lost its competitive position as an entrepot, so that the local regime of accumulation dislocated and nexuses began to move. Yet the cities north of Lake Van to Ani's south were similarly taxed, but apparently not to the same level given their previous relative lack of commerce, so that, in a dynamic Ibn Khaldūn would recognise, both commerce and tax revenue increased simultaneously.

193 "State civilisation « refers to the total complex of interlocking historical social systems often termed »class society", and forming a more or less coherent world system over the long term. See Öcalan, Manifesto; Cf. Frank and Gills, World System. 
In terms of political economy, then, such dynamics represent the contradictory symbiosis between capital and tax. Taxation is not simply a negative extraction from capital accumulation, it constitutes a form of value appropriation, distribution and realisation in its own right. Like capital, taxation rests on the exploitation of surplus labour in the form of money, appropriated by a state system and distributed to maintain a state elite who reinvest to reproduce their class position - in this story the Mongol elite obtaining the rights to revenues from territorial fiscal units, alongside appointed officials like Aziz-Khoja in Tbilisi. ${ }^{194}$ As the elite class expands, so does the need to expand tax revenue, a drive distinct from but comparable to capital's constant need to grow or die, especially insofar as both dynamics generate sites of accumulation through accumulating cores' exploitation of surplus-producing peripheries. Thus both drives manifest historically in urbanisation, as state and mercantile elite classes reinvest appropriated surplus in expanding urban infrastructure, but for the different necessities of tax-based and capitalist accumulation. Moreover, although they represent distinct regimes of accumulation, nevertheless tax and capital presuppose each other: merchant and finance capital functions to provide subaltern actors with the coin necessary to pay tax; while tax creates the conditions in which capital becomes necessary and provides all its predicates: currency, a juridical regime, coercive force, and so on. However, as much as tax and capital presuppose each other, each necessarily seeks to dominate the other, either making capital handmaiden to tax-based accumulation - as for the majority of state civilisation's history or tax auxiliary to capital accumulation - as has been the story of capitalist modernity. Tax and capital form two aspects of a single dialectic, so that in any given configuration one must be hegemonic over the other, a contradiction heightened if the regime of accumulation enters crisis. In concrete historical terms, this contradictory symbiosis between tax-based and capitalist regimes of accumulation is expressed in their representative classes' struggle for political hegemony in the state system.

In the case of Ani's urbanisation the dialectic between tax and merchant capital played out initially to the benefit of both tax-based and merchant capitalist accumulation: the city developed into an urban polity either relatively autonomous within a broader tax-based state system, as under the empire of New Rome or the early Mongol period, or in which merchant capital appears hegemonic and taxation more or less reduced to skimming from commerce, as in the twelfth century Shaddadid emirate and the Zakarian-Mkhargrdzeli regime under the Georgian kingdom. By the later thirteenth century, however, Ani's regime of accumulation was firmly subordinated to a role of providing tax revenue to reproduce the Ilkhans' state system - it had become a periphery to a new tax-accumulating core within the same region, Tabriz, and this internal connection between the two cities' (de-)urbanisations requires further research alongside a more general analysis of merchant capital and urbanisation in the Ilkhanate. Tax left Ani and its environs to reproduce Tabriz's urbanisation - in Ibn Khaldūn's terms a new state system dictating a new process of "civilisation « - which itself also rested on capital accumulation, an example of tax and capital combining as complementary vectors. ${ }^{195}$ In Ani, conversely, the contradiction heightened to the point that the city no longer

194 Cf. Banaji, Theory, 15-40.

195 Cf. Wing, »Rich in Goods«; and Blair, Tabriz. 
accumulated enough from capital to perform the role of a tax-producing periphery, and capital's representatives, the mercantile elite, performed a "spatial fix" and moved to Astrakhan and elsewhere, where the conditions for capital accumulation were better met. ${ }^{196}$ Yet Ani's elite also reproduced itself through village rentierism, a political-economic category and dynamic requiring further research in this historical instance. The long thirteenth century's close thus manifested in a bifurcation in the merchant-rentier regime of accumulation, with elite actors forced into primarily reproducing themselves either as landlords or as merchants. No doubt many chose the former, integrating with and evolving into the region's class of landowning, village-dominating aghas and maliks.

Overall Ani's urbanisation was an outcome of the balance of forces between, on the one hand, intra-elite struggles to generalise the dominance of a given form of accumulation and realise class power in the political regime, and, on the other, the extent to which elite classes as a whole were able to coerce subaltern classes, overcome their counterpolitical struggles, and further expand accumulation in general. In Ani the result of intra-elite struggles was ultimately the hegemony of tax, and the relocation of capital as both commerce and subaltern classes left. Ani's merchant-rentiers had been able to leverage capital's class power in the regime of accumulation, but capital could not conquer the state system, a development which only took place in the medieval West and proved the crucial moment in capitalist modernity's eventual coalescence. ${ }^{197}$ Nevertheless, in the story of merchants moving from Ani to Astrakhan we find a clear example of capitalists as such: elite actors whose class position relied on the cost-benefit analyses of competition, profit and productive reinvestment to expand the enterprise, spending money to invest in or buy commodities to sell for a return of more money, ${ }^{198}$ relocating over $1000 \mathrm{~km}$ to assure their social reproduction on this basis. This in itself plots Ani as a crucial site in the nascent Armenian merchant bourgeoisie's longterm trajectory of accumulation, those actors so prominent in the commercial capitalism which forged the modern world system after the fourteenth century.

196 Cf. Harvey, Globalization.

197 Cf. Banaji, Commercial Capitalism.

198 In Marxian terms M-C-M'; see Marx, Capital, 247-269. 


\section{Acknowledgments}

As ever, I must thank my dear friends and comrades Ilya Afanasyev and Lorenzo M. Bondioli for their mutual aid in (co-)writing this piece. I must also thank Jairus Banaji, Kathryn Franklin, Rachel Goshgarian, Jules Joanne Gleeson, Tim Greenwood, Mirela Ivanova, Zara Pogossian, Alexandra Vukovich and Chris Wickham, as well as Medieval Worlds' anonymous reviewer, for providing crucial comments and criticisms. Finally, my deepest gratitude goes to Matthew Kinloch and Bruno De Nicola for their kind invitation to consider these themes and centuries at a fruitful and engaging workshop; it has proved decisive for my research. 


\section{References}

Abu-Lughod, Janet, Before European Hegemony: The World System A.D. 1250-1350 (Oxford, 1989).

Al-Muqaddasī, The Best Divisions for Knowledge of the Regions, trans. Basil Anthony Collins (Reading, 2001).

Anievas, Alexander and Kerem Nisancioglu, How the West Came to Rule: The Geopolitical Origins of Capitalism (London, 2015).

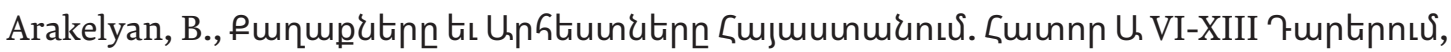
Kaghakner'e yev Arhestner'e Hayastanum. Hator A VI-XIII Darerum [The Cities and Crafts of Armenia: Volume I, 6th-13th centuries] (Yerevan, 1953).

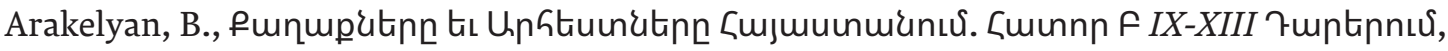
Kaghakner'e yev Arhestner'e Hayastanum. Hator B IX-XIII Darerum [The Cities and Crafts of Armenia: Volume II, 9th-13th centuries] (Yerevan, 1964).

Ashtor, Eliyahu, A Social and Economic History of the Near East in the Middle Ages (Berkeley, 1976).

Attaleiates, Michael, The History, trans. Anthony Kaldellis and Dimitris Krallis (Cambridge MA, 2012).

Babajanyan, Astghik, Results of archaeological excavations at the Selim Caravanserai, Historical-Cultural Heritage 1 (Yerevan, 2014) 146-158.

Babajanyan, Astghik, >On the question of the medieval urban system in the Ararat Plain (Armenia)<, Metsamorian Readings 1 (Yerevan, 2017) 327-344.

Babajanyan, Astghik and Kathryn Franklin, Everyday life on the medieval Silk Road: VDSRS excavations at Arpa, Armenia, Aramazd 12/1 (2018) 155-183.

Babayan, L. H., The development of Zakarid power and new Armenian feudal houses., in: Ts. Aghayan, B. Arakelyan, G. Galoyan, S. Eremyan, L. Khachiyan, A Hakobyan and

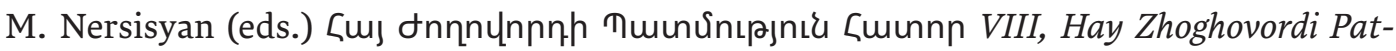
mutyun Hator VIII [History of the Armenian People Vol. 8] (Yerevan, 1976).

Beaujard, Philippe, Globalization during the Song and Mongol periods (tenth-fourteenth century), and the downturn of the fourteenth century, in: Philippe Beaujard, The Worlds of the Indian Ocean: A Global History. Vol. 2 (Cambridge, 2019) 145-430.

Beckwith, Christopher I., Empires of the Silk Road: A History of Central Asia from the Bronze Age to the Present (Princeton, 2009).

Blessing, Patricia, Silk Road without fabrics: Ani at the crossroads of trade and textile motifs in architecture, in: Zaza Shkirtladze (ed.), Ani at the Crossroads (Tbilisi, 2019) 229-254.

Beckert, Sven, Empire of Cotton: A Global History (London, 2014).

Banaji, Jairus, Theory as History: Essays on Modes of Production and Exploitation (Leiden, 2010).

Banaji, Jairus, Merchant capitalism, peasant households and industrial accumulation: Integration of a model, Journal of Agrarian Change 16/3 (2016).

Banaji, Jairus, A Brief History of Commercial Capitalism (Chicago, 2020).

Bayram, Fahriye, Necmettin Alp and Zeynep Akture, Archaeological site of Ani, in: Unesco World Heritage in Turkey (Ankara, 2019) 447-483.

Bedrosian, Robert, The Turco-Mongol Invasions and the Lords of Armenia in the 13-14th Centuries. Unpublished PhD thesis (Columbia University, 1979). 
Bedrosian, Robert, Armenia during the Seljuk and Mongol periods, in: Richard G. Hovannisian, The Armenian People from Ancient to Modern Times. Volume I, The Dynastic Periods: From Antiquity to the Fourteenth Century (New York, 1997).

Bernstein, Henry, Class Dynamics of Agrarian Change (Halifax, 2010).

Blair, Sheila S., Tabriz: International entrepôt under the Mongols, in: Judith Pfeiffer (ed.), Politics, Patronage and the Transmission of Knowledge in 13th-15th c. Tabriz (Leiden, 2014) 321-356.

Concina, Ennio, Fondaci: Architettura, Arte, e Mercatura tra Levante, Venezia, e Alemagna (Milan, 1997).

Constable, Olivia, Housing the Stranger in the Mediterranean World: Lodging Trade, and Travel in Late Antiquity and the Middle Ages (Cambridge, 2009).

Cowe, S. Peter (ed.), Ani: World Architectural Heritage of a Medieval Armenian Capital (Leuven, 2001)

Dadoyan, Seta B., The Armenians in the Medieval Islamic World, 3 vols. (London, 2011-2014).

Dashdondog, Bayarsaikhan, The Mongols and the Armenians (1220-1335) (Leiden, 2011).

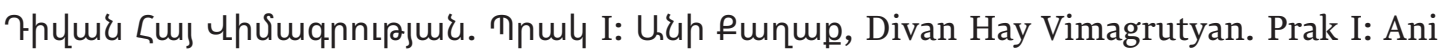
Kaghak [Corpus of Armenian Inscriptions. Vol. I: The City of Ani], ed. H. A. Orbeli (Yerevan, 1966).

Eastmond, Anthony, Tamta's World: The Life and Encounters of a Medieval Noblewoman from the Middle East to Mongolia (Cambridge, 2017).

Frank, Anders G., and Barry K. Gills (eds.), The World System: Five Hundred Years or Five Thousand? (Abingdon, 1993).

Franklin, Kate, "This World is an Inn": Cosmopolitanism and Caravan Trade in Late Medieval Armenia. Unpublished PhD Thesis (University of Chicago, 2014).

Franklin, Kate, Early results of research into trade routes and political economy of medieval North Armenia, Habitus (Yerevan, 2014) 304-316.

Franklin, Kate, A house for trade, a space for politics: Excavations at the Arai-Bazarjugh late medieval Caravanatun, Armenia, Anatolica 40 (2014) 1-21.

Franklin, Kate, Assembling subjects: World building and cosmopolitics in late medieval Armenia, in: Emily M. Bonney, Kathryn Franklin and James A. Johnson (eds.), Incomplete Archaeologies (Oxford, 2015) 131-148.

Franklin, Kate, Tasha Vorderstrasse and Frina Babayan, Examining the late medieval village from the Case at Ambroyi, Armenia, Journal of Near Eastern Studies 76/1 (2017) 113-138.

Franklin, Kate, Everyday Cosmopolitanisms: Living the Silk Road in Medieval Armenia (California, 2021).

Gosh, Mkhitar, The Lawcode (Datastanagirk'), trans. Robert W. Thomson (Amsterdam, 2000).

Graeber, David, Towards an Anthropological Theory of Value (London, 2001).

Graeber, David, Debt: The First 5000 Years (New York, 2011).

Greenwood, Tim, The emergence of the Bagratuni kingdoms of Kars and Ani, in: Richard G. Hovannisian (ed.), Armenian Kars and Ani (Costa Mesa, 2011) 43-64.

Grigor of Akner, History of the Nation of the Archers, ed. Robert Blake and Richard Frye, Harvard Journal of Asiatic Studies, vols. 3-4 (1949) 269-443.

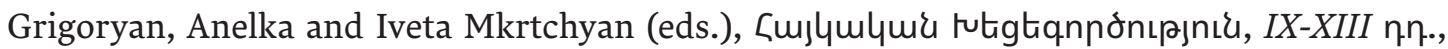
7-uhu, Uih, Haykakan Khetsegortsutyun, IX-XIII dd. [Armenian Ceramics, 9th-13th cc., Dvin, Ani] (Yerevan, 2014)

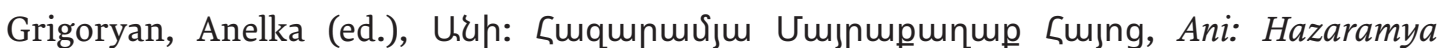
Mayrakaghak [Ani: The Millenial Capital of Armenia] (Yerevan, 2015) 
Hakobyan, T. Kh., Uน̌hh Tuuunúnıљnıน, Anii Patmutyun [A History of Ani] (Yerevan, 1982). Harvey, David, Globalization and the "Spatial Fix«, Geographische Revue 2 (2001) 23-30.

Hovannisian, Richard G., The Armenian People from Ancient to Modern Times. Volume I, The Dynastic Periods: From Antiquity to the Fourteenth Century (New York, 1997).

The Horomos Inscriptions, ed. Samvel Karapetyan and Jean-Pierre Mahé, in: Edda Vardanyan (ed.), Horomos Monastery: Art and History (Paris, 2015) 361-493.

Ibn Khaldūn, The Muqaddimah: An Introduction to History, trans. Franz Rosenthal (Princeton, 1967 repr. 2015).

Kaldellis, Anthony, Romanland: Ethnicity and Empire in Byzantium (Cambridge Mass., 2019). Kirakos of Ganja, History of the Armenians, ed. K.A. Melik-Ohanjanyan (Yerevan, 1961).

jurnosmol zbmz'rgods (K'art'lis C'xovreba). History of Georgia, ed. Stephen Jones et al. (Tbilisi, 2014).

Lacoste, Yves, Ibn Khaldun (London, 1984).

La Porta, Sergio, Reconstructing Armenia: Strategies of co-existence amongst Christians and Muslims in the thirteenth century, in: Barbara Crostini and Sergio La Porta (eds.), Negotiating Co-Existence: Communities, Cultures and Convivencia in Byzantine Society (Trier, 2013) 251-272.

Lopez, Robert S., The Commercial Revolution of the Middle Ages, 950-1350 (Cambridge, 1976)

Mahé, Jean-Pierre, Nicolas Faucherre, Beyhan Karamagarali, and Philippe Dangles, L'Enceinte Urbaine d'Ani (Turquie Orientale): Problèmes Chronologiques, Comptes rendus des séances de l'Académie des Inscriptions et Belles-Lettres 2 (1999) 731-756.

Manandian, Hakob A., The Trade and Cities of Armenia in Relation to Ancient World Trade, translated by Nina G. Garsoïan (Lisbon, 1965)

Marr, Nicolas Yacovlevich, Ani: Rêve d’Arménie (Paris, 2001)

Marx, Karl, Capital Vol. I (London, 1976)

Milios, John, The Origins of Capitalism as a Social System: The Prevalence of an Aleatory Encounter (Abingdon, 2018).

Minorsky, Vladimir, Studies in Caucasian History (London, 1953).

Mutafian, Claude, Ani after Ani, eleventh to seventeenth centuries, in: Richard G. Hovannisian (ed.), Armenian Kars and Ani (Costa Mesa, 2011) 155-170.

Öcalan, Abdullah, Manifesto for a Democratic Civilization, Vols. I-II, translated by Havin Guneser (Porsgrunn, 2015 and 2018).

Orbelean, Stepannos, History of the State of Sisakan, ed. Karapet Shahnasareants (Paris, 1859).

Ostrowski, D. The "Tamma" and the dual-administrative structure of the Mongol Empire, Bulletin of School of Oriental and African Studies, 61/2 (1998) 262-277.

Patlagean, Evelyne, Byzance et les Marchés du Grand Commerce vers 830-vers 1030. Entre Pirenne et Polanyi, in: Mercati e Mercanti Nell'Alto Medioevo: L'Area Euroasiatica e L'Area Mediterranea (Spoleto, 1993) 587-629.

Peacock, Andrew, Black Sea trade and the Islamic world down to the Mongol period, in: Gulden Erkut and Stephen Mitchell, The Black Sea: Past, Present and Future (Ankara, 2007) 65-72.

Peacock, Andrew, An interfaith polemic of medieval Anatolia: Qadi Burhan al-Din al-Anawi on the Armenians and their heresies, in: idem, Bruno De Nicola and Sara Nur Ylldız (eds.), Islam and Christianity in Medieval Anatolia (Farnham, 2015) 233-261.

Peacock, Andrew, Waqf inscriptions from medieval Anatolia, in: Oguz Tekin, Christopher H. Roosevelt and Engin Akyurek (eds.), Philanthropy in Anatolia through the Ages (Istanbul, 2020) 183-193. 
Pogossian, Zaroui, The Foundation of the monastery of Sevan: A case study on monasteries, economy and political power in IX-X century Armenia, in: Letizia Ermini Pani (ed.), Le Valli dei Monaci (Spoleto, 2012) 181-215.

Pogossian, Zaroui, Women, identity and power: a review essay of Antony Eastmond, Tamta's World, Al- 'Ușūr al-Wusțā 27 (2019) 233-266

Preiser-Kapeller, Johannes, Civitas Thauris. The significance of Tabriz in the spatial frameworks of Christian merchants and ecclesiastics in the 13th and 14th century, in: Judith Pfeiffer (ed.), Politics, Patronage and the Transmission of Knowledge in 13th-15th Century Tabriz (Leiden, 2014) 251-300.

Rayfield, Donald, Edge of Empires: A History of Georgia (London, 2012)

Schurmann, Herbert F. Mongolian tributary practices of the thirteenth century, Harvard Journal of Asiatic Studies 19, No. 3/4 (1956) 304-389.

Shiba, Yoshinobu, Commerce and Society in Sung China (Michigan, 1970)

Sinclair, Thomas A., Eastern Turkey: An Architectural and Archaeological Survey Vol. I (London, 1987).

Sinclair, Thomas A., Trade, administration, and cities on the plateau of Kars and Ani, thirteenth to sixteenth century, in: Richard G. Hovannisian (ed.), Armenian Kars and Ani (Costa Mesa, 2011) 171-206.

Sinclair, Thomas A., Eastern Trade and the Mediterranean in the Middle Ages: Pegolotti's Ayas-Tabriz Itinerary and its Commercial Context (Farnham, 2019).

Skylitzes, Ioannes, A Synopsis of Byzantine History, trans. John Wortley (Cambridge, 2010).

Smith, John M., Mongol and nomadic taxation, Harvard Journal of Asiatic Studies 30 (1970) 46-85.

Sneath, David, The Headless State: Aristocratic Orders, Kinship Society, and Misrepresentations of Nomadic Inner Asia (New York, 2007).

Ter-Ghevondyan, Aram, The Arab Emirates in Bagratid Armenia, translated by Nina Garsoïan, (Lisbon, 1976).

Trépanier, Nicholas, Foodways and Daily Life in Medieval Anatolia (Austin, 2014).

Van Bruinessen, Martin, Agha, Sheikh and the State: The Social and Political Structures of Kurdistan (London, 1992).

Vardanyan, Edda (ed.), Horomos Monastery: Art and History (Paris, 2015).

Wallerstein, Immanuel, The Modern World-System I: Capitalist Agriculture and the Origins of the European World-Economy in the Sixteenth Century (Berkeley, 1974).

Wallerstein, Immanuel, The Modern World-Sytem II: Mercantilism and the Consolidation of the European World-Economy, 1600-1750 (New York, 1980).

William of Rubruck, The Mission of Friar William of Rubruck, trans. Peter Jackson and David Morgan (London, 1990).

Wing, Patrick "Rich in Goods and Abounding in Wealth«: The Ilkhanid and Post-Ilkhanid ruling elite and the politics of commercial life at Tabriz, 1250-1400, in: Judith Pfeiffer (ed.), Politics, Patronage and the Transmission of Knowledge in 13th-15th c. Tabriz (Leiden, 2014) 301-320.

Ylldı, Sara Nur, Post-Mongol pastoral polities in Eastern Anatolia during the Late Middle Ages, in: Deniz Beyazit (ed.), At the Crossroads of Empires: 14th-15th Century Eastern Anatolia (Paris, 2012) 27-48.

Zhang, Ling, The River, the Plain, and the State: An Environmental Drama in Northern Song China, 1048-1128. 